See discussions, stats, and author profiles for this publication at: http://www.researchgate. net/publication/47617554

\title{
The Right to Food and Buyer Power
}

ARTICLE in SSRN ELECTRONIC JOURNAL • OCTOBER 2010

DOI: $10.2139 /$ ssrn.1699870 · Source: OAI

CITATION

1

1 AUTHOR:

Aravind Ganesh

Max Planck Institute Luxembourg for Interna...

8 PUBLICATIONS 2 CITATIONS

SEE PROFILE
READS

6 


\title{
Articles
}

\section{The Right to Food and Buyer Power}

\author{
By Aravind R. Ganesh ${ }^{*}$
}

\begin{abstract}
Modern global food supply chains are characterized by extremely high levels of concentration in the middle of those chains. This paper argues that such concentration leads to excessive buyer power, which harms the consumers and food producers at the ends of the supply chains. It also argues that the harms suffered by farmers are serious enough as to constitute violations of the international human right to food, as expressed in the Universal Declaration of Human Rights and more specifically, in the International Covenant on Economic, Social and Cultural Rights. World competition law regimes cannot ignore these human rights imperatives. To a certain extent, these imperatives can be accommodated under existing consumerist competition law theories by the interpretive mechanism of conform-interpretation. However, when one comprehends the truly global scale of modern food supply chains, it becomes obvious that conform-interpretation alone will not suffice. Instead, the protection of a minimum level of producer welfare congruent to those producers' right to a minimum adequate level of food must find a place among the aims of any credible theory of competition law. Moreover, the same globalized nature of these food supply chains means that current doctrines of extraterritorial jurisdiction of competition control have also to be revised.
\end{abstract}

\section{A. Introduction}

Buyer power in food supply chains has been an issue of concern for agricultural policymakers and regulators the world over for the last few years. In 2008, a majority of the members of the European Parliament adopted a declaration requesting the European Commission to address "the abuse of power by large supermarkets operating in the European Union." ${ }^{1}$ Over the course of the past decade, the U.S. Senate conducted a

*LL.B(Hons) (King's College, London, 2008), J.D. (Columbia, 2008), B.C.L. (Oxford, 2010). Visiting Scholar, Université Catholique de Louvain, (October 2009 - December 2010); Research Associate to the UN Special Rapporteur for the Right to Food. The ideas and recommendations contained in this paper do not bind or represent the positions of the Special Rapporteur or of the UN in any way, shape or form. I would like to thank Dr. Christine Jesseman for her kind assistance and extremely insightful comments. All mistakes are mine alone.

Declaration tabled by Caroline Lucas (Verts/ALE/UK), Gyula Hegyi (PSE/HU), Janusz Wojciechowski (UEN/PL), Harlem Désir (PSE/FR) and Hélène Flautre (Verts/ALE/FR) pursuant to Rule 116 of the European 
number of hearings into concentration in agricultural markets. ${ }^{2}$ Moreover, at the time of writing, the U.S. Department of Justice and the Department of Agriculture were holding a series of public workshops to deal with buyer power, concentration and vertical integration. ${ }^{3}$ At the opening of these workshops, US Attorney-General Eric Holder issued a press statement expressing concern over the high levels of concentration in a number of US agricultural markets. ${ }^{4}$ He also noted ${ }^{5}$ that this marked the first time in American history that both the Departments of Justice and Agriculture had dealt with the issue in a public setting. ${ }^{6}$

Quite a few judicial and regulatory bodies have also taken up the issue of excessive buyer power in food supply chains. Examples of such engagement by competition authorities include the Groceries Market Investigations of 2000 and 2008 by the UK Competition Commission, and the investigation of the alleged milk cartel by the South African Competition Commission. The latter milk cartel was investigated for, among other things, allegedly colluding to fix the purchase price of milk, as well as imposing contracts upon dairy farmers requiring them to supply their total milk production. ${ }^{7}$ More recently, an investigation was launched into the supermarket industry, with the Competition Commission specifically citing as being of concern the exclusion of small producers from access to retail shelves as a result of buyer concentration. ${ }^{8}$

Parliament's Rules of Procedure, EP reference number: DCL-0088/2007 / P6-TA-PROV(2008)0054. See, Myriam Vander Stichele and Bob Young, The Abuse of Supermarket Buyer Power in the EU Food Retail Sector: Preliminary Survey of Evidence, Agribusiness Accountability Initiative (March 2009, Amsterdam).

${ }^{2}$ U.S. Senate Judiciary Committee Hearing, Ensuring Competitive and Open Agricultural Markets: Are Meat Packers Abusing Market Power? Sioux Falls, South Dakota, (23 August 2002); U.S. Senate Judiciary Committee Hearing, Monopsony in Markets for Agricultural Products: A Serious Problem in Need of a Remedy, (30 October 2003); U.S. Senate Judiciary Committee Hearing, Concentration in Agriculture and an Examination of the JBS/Swift Acquisitions, (7 May 2008).

${ }^{3}$ See, US. DoJ website: http://www.justice.gov/atr/public/workshops/ag2010/index.htm\#dates (Last Accessed: 23 November 2010). The first of these workshops too place on 12 March 2010, at Ankeny, lowa.

${ }^{4}$ Christopher Leonard, US Attorney General, Agriculture Secretary begin hearings on competition in farming system, (12 March 2010) Associated Press.

${ }^{5}$ Prepared Remarks of U.S. Attorney General Eric Holder, DoJ and USDA Agriculture Workshop, Ankeny, lowa, (12 March 2010). Available at: http://www.justice.gov/ag/speeches/2010/ag-speech-100312.html.

${ }^{6}$ This is, however, not the first time U.S. governmental institutions have broached the issue. See, supra, note 2.

${ }^{7}$ Press Statement, Milk Cartel Hearings Set, Competition Commission of South Africa, (7 Feb 2008). The investigation has so far remained bogged down on procedural questions, with the Supreme Court of Appeal ruling that the Competition Commission's initiation of the complaint against two of the alleged cartel members, as well as the referral of those complaints to the Competition Tribunal, had both been improper: Woodlands Dairy $v$. Milkwood Dairy (105/2010) [2010] ZASCA 104 (13 September 2010).

${ }^{8}$ Press Statement, Competition Commission to probe the supermarket industry, Competition Commission of South Africa, (29 June 2009). 
Apart from these better-known examples, fair trade and competition authorities in Korea, Taiwan and Thailand have brought actions against dominant buyers for various kinds of abusive conduct. Between 1999 and 2001, the Korean Fair Trade Commission (KFTC) prosecuted Wal-Mart and Carrefour for conduct that included unfair refusal to receive products, unfair return of products, unfair price reductions, unfair passing on of advertising fees to producers, etc. The KFTC imposed fines on both Wal-Mart-Korea and KoreaCarrefour and ordered both companies to publicize the fact of their abusive conduct in newspapers. ${ }^{9}$ In Taiwan, a Commission established pursuant to the Fair Trade Law of 1991 identified six types of unfair retailer practice, ranging from charging improper fees to unreasonable penalties for supply shortages. The Taiwanese Commission has since published a set of guidelines for the charging of such additional fees by retail chains. ${ }^{10}$ In Thailand, a specialized commission was tasked with studying the issue of buyer power after competition authorities received a spate of complaints regarding unfair trade practices. ${ }^{11}$

An important question is whether the legal response - of which antitrust or competition law undoubtedly forms the major part - should be conceived purely as a matter of choosing between good and bad policy options, or whether human rights norms have some application. It is the argument of this paper that the international human right to food indeed applies. In the next section, I shall describe the structure and design of global agricultural markets and food supply chains. In the third section, I shall summarize the international human right to food, as expressed in various international instruments as well as in constitutional documents, and the obligations arising under it, which will demonstrate that the human right to food must indeed feature in the policy debate over buyer power. This means that competition laws should ensure the protection of a minimum amount of producer welfare such as would be necessary for producers to have access to adequate food. In the fourth, I shall argue that the prevailing conception of competition law; i.e. as a tool for the protection of consumers as its main or even sole priority (the "consumerist approach") may coincide to a significant extent with such human rights norms. In this vein, I shall set out the arguments for why the creation or maintenance of dominant buyer power is antithetical to the long-term (and in some cases the short- or medium-term) interests of consumers, particularly those in developed countries, as well as the arguments for why competition law should control such developments.

\footnotetext{
${ }^{9}$ S. K. Jhong, Anti-competitive practices at the distribution sector in developing countries, APEC Training Program on Competition Policy paper, $9-10$ (2003) and Liz Dodd \& Samuel Asfaha, Rebalancing the Supply Chain: buyer power, commodities, and competition policy, (April 2008), South Centre \& Traidcraft, 23.

${ }^{10}$ G. Lin, Taiwan's Competition Law Enforcement Experience and Cases in Retailing Business, APEC Training Program on Competition Policy paper, 2 - 5. Op. cit. Dodd \& Asfaha, supra, note 9, 23 (2003).

${ }^{11}$ Note submitted by Thailand, How enforcement against private anti-competitive practice has contributed to economic development, OECD Global Forum on Competition (2004).
} 
In the fifth part of the paper, I shall set out an argument for why currently dominant consumerist approaches to competition law, are nevertheless inadequate. Instead, a conceptual shift has to be made to a theory of competition control which recognizes the importance of protecting and advancing human rights such as the right to food. This is a "shift" to a new theory of competition law, and not a "return" to the ordoliberal theories of competition that were in vogue between the 1950s and the 1970s. Lastly, I shall examine the extraterritorial reach of pure consumer welfare-based competition laws, and those that incorporate right to food concerns.

First, some clarifications are necessary. A number of the terms in this paper are used in an ecumenical spirit, due to the fact that the language used by lawyers from different jurisdictions varies considerably. By "competition law", I mean all those bodies of law focused on avoiding harm to the competitive process, ${ }^{12}$ regardless of whether they are termed "antitrust" or "fair trading" laws in their home jurisdictions. Likewise, by "firms", I mean all market actors regardless of legal or natural personality, and regardless of whether they are called "undertakings", etc, in their home jurisdictions. Other such terms are to be treated similarly: a safe rule of thumb for the reader would be to understand the terms used in the paper in their natural, rather than technical meaning. However, other terms have a more specific meaning. By "buyer power", I mean the form of market power that allows a buyer, to extract better terms from suppliers than would otherwise be the case. ${ }^{13}$ As for the phrase "extraterritorial reach", I use it in a novel sense. It refers not just to the various doctrines of personal or subject-matter jurisdiction and comity, but to all the rules and principles of competition law that may affect conduct of firms and undertakings outside the jurisdiction. The need for this will hopefully become evident as I discuss the obligation of "international cooperation".

Finally, the reader should be aware that the U.S. is not a party to the International Covenant on Economic, Social and Political Rights (ICESCR). ${ }^{14}$ The right to food is accordingly not recognized by the U.S. at the international level, let alone at the municipal. Instead, I discuss U.S. antitrust law for two reasons: because it is of use in demonstrating the extent to which consumer welfare concerns coincide with right to food considerations, and because U.S. antitrust law and precedents often influence the competition regimes of other countries which are party to the ICESCR.

\footnotetext{
${ }^{12}$ RICHARD WHISH, COMPETITION LAW 2 (2009).

${ }^{13}$ This is modelled on the definition provided by the UK Competition Commission, Groceries Market Investigation 155 (2008), (note 2): "Buyer power is a form of market power that a grocery retailer may have with respect to its suppliers that allows the grocery retailer to extract better terms from its suppliers than would otherwise be the case.".

${ }^{14}$ International Covenant on Economic, Social and Cultural Rights art. 11, 16 Dec 1966, 993 UNTS 3.
} 


\section{B. Buyer concentration and The Nature of world hunger}

\section{Some facts about global hunger and food supply chains}

According to the latest statistics, an estimated 925 million ${ }^{15}$ people are presently suffering from hunger, which works out to just under one in every six persons. One exquisite irony about current hunger statistics is the fact that the people most likely to be going hungry are not consumers, but rather those who are involved in the making and production of food. According to a survey done by the UN Millennium Project in 2005, farmers cultivating small patches of land ("smallholders") and landless agricultural workers together made up around $70 \%$ of the people suffering from hunger. ${ }^{16}$ Another arresting feature of this landscape is the fact that such widespread hunger is not due to food production declining or being unable to catch up with population growth: some of the most celebrated scholars in the field have consistently observed that food production is generally increasing. ${ }^{17}$ Even though, at the time of writing, it appears that world cereal prices will rise significantly over the coming months as a result of export bans resulting from droughts and massive fires in Russia as well as other countries, the FAO finds that the 2010 global cereal crop is still the third highest on record. ${ }^{18}$ Rather, it is the faulty distribution of food via markets that leads to the starvation of millions despite there being more than enough food to go around for everyone. Indeed, for the first time in history, obese people now actually outnumber the starving. ${ }^{19}$ The fundamental reason for such perverse deprivation in the midst of abundance is the widespread inability to buy food in the market due to insufficient incomes. ${ }^{20}$

\footnotetext{
${ }^{15}$ Website of the UN Food and Agriculture Organisation (FAO): http://www.fao.org/hunger/en/ (Last Accessed: 22 November 2010).

${ }^{16}$ See, UN Millennium Project, Halving Hunger: It Can be Done, Summary Version of the Report of the Task Force on Hunger, The Earth Institute, Columbia University, 6 (2005).

${ }^{17}$ Amartya Sen, Development as Freedom 160 - 188 (1999). See, also Susan George, How the Other Half Dies, London: Penguin 23 (1991) and SUSAN MARKS \& ANDREW CLAPHAM, INTERNATIONAL HUMAN RIGHTS LEXICON 167 (2005). Sen observes that colonial administrators in Bengal during the 1943 famine "were so impressed by the fact that there was no significant food output decline... that they failed to anticipate - and for some months even refused to recognize - the famine as it hit Bengal with stormy severity." DEVELOPMENT AS FREEDOM, 209. Moreover, he notes that that the Bangladesh famine of 1974 occurred at a time period of "peak food availability", food having been available in greater quantities than at any other time between the years 1971 and 1976: id. 165.

${ }^{18}$ Global cereal supply and update, FAO/GIEWS Global Watch, (1 Sept 2010).

${ }^{19}$ Raj PATel, Stuffed And StARVed 1 (2008).

${ }^{20}$ DeVElopment As Freedom, 171.
} 
The third astonishing feature of that landscape is the extreme level of concentration in the middle of global food supply chains. Consider the following figures. In 2008, the World Bank estimated that 2.5 billion people around the world farmed for a living. ${ }^{21}$ To take one commodity in particular, those who grew coffee numbered about 25 million. At the other end of the chain, there were around 500 million consumers of coffee. However, at the middle of the chain, we observe that the concentration ratio (i.e. the market share of the top four firms) of the coffee roasting industry was $45 \%$, and that of international coffee trading was $40 \% .^{22}$ The same World Bank report states that just three companies controlled over $80 \%$ of the world's tea markets, while concentration ratios were $40 \%$ in international trading in cocoa, $51 \%$ in cocoa grinding, and $50 \%$ in confectionary manufacturing ${ }^{23}$ respectively. In the Brazilian soybean market, roughly 200,000 farmers attempt to sell to five main commodity traders, and three large transnational commodity buyers (ADM, Cargill, and Barry Callebaut) dominate the Ivorian cocoa industry. As for food processors, in 1996, two transnational food and beverage companies, Nestlé and Parmalat, shared $53 \%$ of the Brazilian dairy processing market, allegedly driving out a large number of cooperatives, which then had to sell their facilities to these companies. ${ }^{24}$ Never before in history, it appears, have so many consumers and so many farmers bought and sold through so few middlemen.

\section{Concentration and Global Hunger}

The main argument of this paper is that the extreme levels of concentration among buyers situated in the middle of food supply chains must be a significant causal factor behind the levels of global hunger, because extreme buyer concentration reduces the number of options available to sellers, i.e. farmers. Such concentration gives such buyers thereby considerable power to set the terms, conditions, and prices in their dealings with farmers,

\footnotetext{
${ }^{21}$ World Bank, World Development Report 2008: Agriculture for Development, 3, 29 (November 2007). See, also Sophia Tickell, Fairtrade in perspective, (2004) Sustainability Radar. Op. cit. Dodd \& Asfaha, supra, note $9,9$.

${ }^{22}$ World Development Report 2008, 135 - 136.

${ }^{23}$ Id. 136.

${ }^{24}$ See, Peter Gibbon, The Commodity Question: New Thinking on Old Problems, Human Development Report Office, Occasional Paper, 2005/13 and Bill Vorley, Food Inc.: Corporate Concentration From Farm to Consumer, United Kingdom Food Group, (2003), available at: http://www.ukfg.org.uk/docs/UKFG-Foodinc-Nov03.pdf, and Mary Hendrickson et al., The Global Food System and Nodes of Power (2008), available at SSRN: http://ssrn.com/abstract=1337273 (Last Accessed: 23 November 2010) and Molly Anderson, A Question of Governance: To Protect Agribusiness Profits or the Right to Food?, Agribusiness Action Initiatives (2009) and A. Sheldon and R. Sperling, Estimating the Extent of Imperfect Competition in the Food Industry: What Have We Learned? (2003), 54 J. OF AgRICULtURAL ECONOMICS 1. Also quoted in Olivier De Schutter, "Agribusiness and the right to food", Report of the Special Rapporteur on the right to food to the Human Rights Council, A/13/33, 5 (note 14) (22 December 2009).
} 
thereby depriving farmers of the ability to earn enough income to feed themselves adequately. For instance, studies have shown that the practice of dominant UK groceries retailers of passing on to Kenyan producers the cost of compliance with the retailers' private standards on hygiene, food safety and traceability has resulted in the moving away of food production from smallholders to large farms, "many of which were owned by the exporters", as well as the acquisition by such exporters of their own production capacity. ${ }^{25}$ In short, small farmers are being excluded from global grocery supply chains, thus severely damaging their incomes.

The damage caused by buyer power is exacerbated by the "commodity problem"; i.e. by the tendency of the supply of many agricultural commodities to increase in response to a reduction in price. A recent study by ActionAid and the South Centre demonstrates a positive correlation between concentration in coffee markets and the ever-decreasing proportion of the value of the finished coffee product that reaches farmers. ${ }^{26}$ Coffee is indeed the prime example of this phenomenon: the land on which coffee is cultivated is very hilly and located at high altitudes, making it difficult for farmers to grow anything else commercially. Thus, should the price of coffee fall due to an increase in buyers' bargaining strength, farmers would lack the option of cultivating other crops. Instead, given that they have to eat every day, pay the rent or mortgage on the land, etc, they produce even more coffee in an attempt to earn income in the short-term, thereby causing oversupply and depressing coffee prices further, even below the average cost of production. In essence, producer welfare is appropriated again and again in a vicious circle ending only when producers "leave the market", which, in the case of Kenyan coffee farmers, means the uprooting of entire villages and their resettlement in urban slums. ${ }^{27}$

Excessive reduction of farmers' incomes also breeds other evils. For example, in an effort to reduce costs, food manufacturers may dispense with proper environmental precautions in dumping waste materials, or poor farmers may be driven into making their children work on the farm: as a result of concentration among buyers in the cocoa market in Cote d'Ivoire, agricultural wages were so severely depressed that that there were reports of small-hold cocoa farmers resorting to using child labor. ${ }^{28}$ The vast majority of child labor

${ }^{25}$ Catherine Dolan \& John Humphrey, Changing Governance Patterns in the Trade in Fresh Vegetables between Africa and the United Kingdom, GLOBALISATION \& POVERTY, 17 - 18 (2004).

${ }^{26}$ Samuel Asfaha, Commodities dependence and development: some suggestions on how to tackle the commodities problems, South Centre \& ActionAid (2008).

27 See, e.g. Charis Gresser and Sophia Tickell, Mugged: Poverty in Your Coffee Cup, 22 - 23 (2002); Stuffed AND STARVED, 8-11; and Asfaha, supra, note 26, $10-11$.

${ }^{28}$ See, New York University Law Students for Human Rights, Transnational Corporations and the Right to Food 3 (2009), available at: www.chrgj.org/publications/docs/TNCsandRTF.pdf (Last Accessed: 23 November 2010). and Christian Parenti, Chocolate's bittersweet economy: Seven years after the industry agreed to abolish child labor, little progress has been made, Fortune 1 (15 February 2008). 
takes place in agriculture: $70 \%$ of all working children, or 132 million boys and girls between the ages of 5 and $14 .^{29}$

A prima facie claim can therefore be made that buyer concentration along food supply chains (with exceptions) ${ }^{30}$ tends to lead to buyer power in those chains, which in turn (again, with exceptions) $^{31}$ tends to result in the appropriation of the welfare of farmers producing at the bottom of the chain.

\section{The Right to Food}

\section{The Substance of the Right}

The right to food is located in a number of instruments, both international and domestic. ${ }^{32}$ At the international level, the right to food has been recognized since the inception of the post-WWII human rights regime. It is to be found in Article 25 of the Universal Declaration of Human Rights (UDHR) of $1948,{ }^{33}$ which provides that "(everyone) has the right to a standard of living adequate for he health and well-being of himself and his family, including food...."

29 Website of the International Programme on the Elimination of Child Labour, ILO: http://www.ilo.org/ipec/areas/Agriculture/lang--en/index.htm (Last Accessed: 20 November 2010) A recent ILO document states that an estimated $26.4 \%$ of children between the ages of 5 and 14 in Africa are victims of child labour, thus making it the region where the "least progress has been made during the past years towards the elimination of child labour." Moreover, most of these children are employed in agriculture. The report also cites the "persistent lack of basic and social infrastructure and adequate livelihood for their families" as the main reasons for the deterioration of the child labour situation in Africa: Action against child labour 2008 - 2009: IPEC progress and future priorities, International Programme on the Elimination of Child Labour (Geneva, February 2010), 17.

${ }^{30}$ Buyer concentration may not lead to dominance if a number of factors are present, such as, but not limited to, the ease of entry into either the buyer's or the seller's market.

${ }^{31}$ In certain situations, producers may fare better under a monopsonistic market (a market with only one buyer) rather than under an oligopolistic market (a market with a small number of powerful buyers). An example of this would be agricultural marketing boards run in the public interest, rather than for a profit motive. See, S. Murphy, Concentrated Market Power and Agricultural Trade, Ecofair Trade Dialogue, Discussion Paper No. 1, 31-32 (2006), available at: http://www.tradeobservatory.org/library.cfm?refid=89014. (Last Accessed : 20 November 2010)

${ }^{32}$ See, U.N. FAO Legal Office, The Right to Food in National Constitutions, in THE RIGHT TO FOOD IN THEORY AND PRACTICE, available at: http://www.fao.org/Legal/rtf/bkl.htm\#map.

33 Universal Declaration of Human Rights [UDHR] art. 25(1), G.A. Res. 217A (III), U.N. GAOR, 3d Sess., 1st plen. mtg., U.N. Doc. A/810 (12 December 1948). 
This basic expression was subsequently developed upon in Article 11 of the ICESCR, which provides for two interrelated norms: the right to adequate food and the right to be free from hunger. ${ }^{34}$ The bifurcation of the right to food into the two separate norms dispels the common misconception that the right to food is a right to be fed. This obtains only in the most exceptional circumstances. The right against hunger instead requires State Parties to take immediate action "to mitigate and alleviate hunger... in times of natural or other disasters." ${ }^{35}$ The right to be free from hunger is the only right in the entire corpus of the ICESCR and the International Covenant on Civil and Political Rights (ICCPR) of $1966^{36}$ that is described as "fundamental," ${ }^{37}$ and which can therefore be argued to be absolute. This is in contrast to the right to adequate food, which is limited. At the same time, however, it is clear that the right to be free from hunger and the right to adequate food are intimately linked with one another. Alston argues that the right to be free from hunger is a sub-norm under a much broader right to adequate food; the bare minimum expected of a State, which should properly be aiming towards the full realization of the much broader right to adequate food. ${ }^{38}$ On the other hand, a former UN Special Rapporteur for the Right to Food,

${ }^{34}$ See, Philip Alston, International Law and the Human Right to Food, in THE RIGHT TO FOoD, 32 (Philip Alston \& Katarina Tomaševski, eds., 1984); Smita Narula, The Right to Food: Holding Global Actors Accountable under International Law, 10 CoLUM. J. OF TRANS. L. 691, 706 (2006). Article 11 ICESCR provides:

1. The States Parties to the present Covenant recognize the right of everyone to an adequate standard of living for himself and his family, including adequate food, clothing and housing, and to the continuous improvement of living conditions. The States Parties will take appropriate steps to ensure the realization of this right, recognizing to this effect the essential importance of international co-operation based on free consent.

2. The States Parties to the present Covenant, recognizing the fundamental right of everyone to be free from hunger, shall take, individually and through international cooperation, the measures, including specific programmes, which are needed:

(a) To improve methods of production, conservation and distribution of food by making full use of technical and scientific knowledge, by disseminating knowledge of the principles of nutrition and by developing or reforming agrarian systems in such a way as to achieve the most efficient development and utilization of natural resources;

(b) Taking into account the problems of both food-importing and foodexporting countries, to ensure an equitable distribution of world food supplies in relation to need.

${ }^{35}$ U.N. Econ. \& Soc. Council [ECOSOC], Comm. on Econ. Soc. and Cultural Rights, General Comment No. 12: The Right to Adequate Food, § 10, U.N. Doc. E/C.12.1999/5, para. 6 (12 May 1999).

${ }^{36}$ International Covenant on Civil and Political Rights, 16 Dec. 1966, 999 UNTS 171 (ICCPR).

${ }^{37}$ Narula, supra, note $34,706$.

${ }^{38}$ Alston, supra, note 34,9 . 
Asbjørn Eide argues that the right to adequate food is the minimum obligation, the maximum being the obligation to achieve "full realization" as per Art. 2(1) ICESCR. ${ }^{39}$

The meaning and content of the right to adequate food were elaborated by the Committee on Economic, Social and Cultural Rights in General Comment No. 12: The Right to Adequate Food, ${ }^{40}$ which held that states parties are obliged to ensure "physical and economic access at all times to adequate food or means for its procurement." ${ }^{41}$ This is, "inseparable from social justice, requiring the adoption of appropriate economic, environmental and social policies, at both the national and international levels, oriented to the eradication of poverty and the fulfillment of all human rights for all." ${ }^{42}$ The obligation to ensure the adequacy of food also necessarily implies that the supply of food must be sustainable; i.e. that it will be "accessible for both present and future generations." 43 Moreover, such food must be available "in a quantity and quality sufficient to meet the dietary needs of individuals, free from adverse substances, and acceptable within a given culture." ${ }^{44}$ The following dicta by Kroon AJ. of the South African Constitutional Court provide a crisp and elegant expression of the essence of the international human right to food:

“... international law recognizes that the content of the right to food has twin elements of availability and accessibility. The first element refers to a sufficient supply of food and requires the existence of a national supply of food to meet the nutritional needs of the population generally... The second element requires that people be able to acquire the food that is available or to make use of opportunities to produce food for their own use." 45

\footnotetext{
${ }^{39}$ Asbjorn Eide, Strategies for the Realisation of the Right to Food, in HUMAN RIGHTS IN THE TWENTY-FIRST CENTURY: A Global Challenge, 466 - 470 (Kathleen E. Mahoney \& Paul Mahoney eds., 1993).

${ }^{40}$ General Comment No. 12, supra, note 35.

${ }^{41}$ Id. para. 6.

${ }^{42}$ Id. para. 4.

${ }^{43}$ Id. para. 7.

${ }^{44}$ Id. para. 8. See, also paras. $9-11$, and Articles 24(2)(c) and 27 of the Convention on the Rights of the Child [CRC], G.A. Res. 44/25, annex, U.N. GAOR, 44th Sess., Supp. 49 at 167, U.N. Doc. A/44/49 (20 November 1989), (calling upon state parties to take appropriate measures to combat disease and malnutrition by, inter alia, providing adequate nutritious food and clean drinking water); U.N. General Assembly Resolution 57/226: The Right to Food, (affirming "the right of everyone to have access to safe and nutritious food, consistent with the right to adequate food and the fundamental right of everyone to be free from hunger so as to be able fully to develop and maintain their physical and mental capacities." U.N. GAOR, 57th Sess., Supp. No. 49, U.N. Doc. A/RES/57/226 (2003), 2).

${ }^{45}$ Wary Holdings (Pty) Ltd v. Salwo (Pty) Ltd and Anor (CCT78/07) [2008] ZACC 12; 2009 (1) SA 337 (Constitutional Court); 2008 (11) BCLR 1123 (CC) (25 July 2008), para. 85. Footnotes removed.
} 
As for the persons fixed with obligations under the right to food, General Comment No. 12 holds that both state and private ${ }^{46}$ actors have responsibilities in achieving its aims, and that these be fulfilled with all deliberate speed. All parties subject to the right to food are required to acquit their responsibilities arising under the right to adequate food "progressively" through international assistance and cooperation." ${ }^{\prime 49}$

\section{Typology of Duties and Obligations: The Duty to Protect}

Clearly, the obligations arising under the right to food have profound implications for the kinds of policies states should pursue at the municipal level regarding social justice, public health, and environmental protection. Eide visualized the range of claimants and duty bearers with respect to human rights by categorizing the various obligations of States under the right to food as duties to respect, to protect, and to fulfill or facilitate.$^{50}$ The duty to respect can be likened to the physician's motto of "first, do no harm": it is essentially a duty upon the State not to interfere and thereby adversely affect existing access to adequate food. States for instance may not burn the fields and salt the earth upon which unpopular minorities depend for farming. ${ }^{51}$ The duty to protect, on the other hand, requires States "to ensure that enterprises or individuals do not deprive individuals of their access to adequate food." ${ }^{152}$ Lastly, the duty to fulfill or facilitate means that "the State

${ }^{46}$ General Comment No. 12, supra, note 35, para. 20. See, also, John Ruggie, Protect, Respect and Remedy: A Framework for Business and Human Rights, Report of the Special Representative of the Secretary-General on the issue of human rights and transnational corporations and other business enterprises, (Advance Edited Version), $\mathrm{A} / \mathrm{HRC} / 8 / 5,18$ (7 April 2008). Private actors have an obligation to "respect" the right to food, which means they must ensure, with due diligence, that their actions do not actively harm other individuals' rights. Professor Ruggie's framework was a product of three years of consultations with participation by business interests.

${ }^{47}$ Art. 2(1), International Convention on Economic, Social, and Cultural Rights (ICESCR), and General Comment No. 12, supra, note 35, at paras. 6, 14 and 16. See, also, U.N. Comm. on Econ., Soc. \& Cultural Rights [CESCR], General

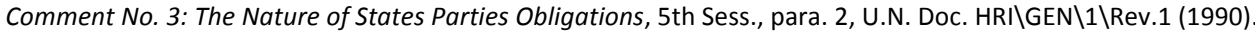

${ }^{48}$ General Comment No. 12, supra, note 35, para. 14.

${ }^{49}$ Art. 2(1), ICESCR. The "fundamental" right to be free from hunger, in contrast, must be vindicated immediately: General Comment No. 12, supra, note 35, para. 6.

${ }^{50}$ U.N. ECOSOC, Sub-Comm. on Prevention of Discrimination \& Prot. of Minorities, The New International Economic Order and the Promotion of Human Rights: Report on the Right to Adequate Food as a Human Right, U.N. Doc. E/CN.4/Sub.2/1987/23 (7 July 1987) (submitted by Asbjørn Eide).

${ }^{51}$ Narula, supra, note 34, $708-711$. See, Amnesty Int'l, Zimbabwe: Power and hunger-violations of the right to food, 10-14, 18-29 (2004).

${ }^{52}$ General Comment No. 12, supra, note 35, para. 15. 
must pro-actively engage in activities intended to strengthen people's access to and utilization of resources and means to ensure their livelihood, including food security." ${ }^{53}$

The interface between the right to food and forms of market regulation such as competition law falls mainly within the State's duty to protect human rights: States "must intervene where acts committed by private parties, whether individuals, groups or legal persons, threaten to violate those rights." ${ }^{54}$ Fundamentally, the duty to protect proceeds from an appreciation of the tremendous influence private actors such as multinational corporations have over individual lives, and of the intimate connections between such private actors and the State. The instances of such power and influence can be separated into two categories. The first category comprises those instances where States and private actors work hand in glove to further private commercial interests. The most notorious examples include $1954 \mathrm{CIA}$-sponsored coup in Guatemala that overthrew the democratically elected government of Jacobo Arbenz Guzmán, at the behest of the United Fruit Company (UFCo), which paved the way for four decades of civil war, ending only in 1996 and resulting in the loss of 200,000 lives. ${ }^{55}$ More commonly, states negotiate bilateral and multilateral investment treaties on behalf of their corporations; offer investment insurance through their export credit agencies to cover the risks of adverse political developments or even simple commercial risks; or even simply throw their prestige and weight behind their corporations in order to pressure other States into renegotiating deals that turn out badly for their domiciliary corporations. ${ }^{56}$

The second category covers those instances where private individuals and corporations exercise power and influence independent of official assistance or complicity, or even in the face of official disapproval. An example of private or corporate power frustrating the best-laid plans of policymakers in the context of the right to food is provided by People's Union for Civil Liberties v. Union of India and Others, ${ }^{57}$ where the Indian Supreme Court issued directions to the federal and state governments of India to put in place certain food

${ }^{53} / d$.

54 Olivier De Schutter, International human Rights LaW. CASES, Materials, References 365 (2010).

55 STUFFED AND STARVED, 100 - 103. He describes the UFCo's animus against the Arbenz administration as arising out of that government's plans to compulsorily purchase land from UFCo which it had declared as unused on its tax returns. UFCo exercised its connections within the Truman and Eisenhower administrations, specifically through Secretary of State John Foster Dulles, to brand Arbenz as a communist radical. Presidential approval was given in 1954 to launch a coup, which was code-named Operation PBSUCCESS.

${ }^{56}$ Narula, supra, note 34, 763. Quoting JOSEPH STIGLITZ, GLOBALIZATION AND ITS DISCONTENTS, 71 (2003): “In Argentina, the French government reportedly weighed in pushing for a rewriting of the terms of concessions for a water utility [Aguas Argentinas], after the French parent company [Suez Lyonnaise] that had signed the agreements found them less profitable than it had thought."

${ }^{57}$ Writ Petition [Civil] No. 196 of 2001 (Supreme Court of India). 
aid schemes. The Court also appointed a Commissioner to supply it from time to time with reports on the implementation of those directions. In the Fourth Report, the Commissioner found that,

"... the orders passed so far are not equal to the task of guaranteeing freedom from hunger in India, and even these orders have been routinely violated. Bolder action is needed if the right to food is to become a reality." 58

The cry for "bolder action" demonstrates the insufficiency not just of a strategy of trying to fulfill the right to food merely by issuing orders from on high, but also of such orders being unaccompanied by market regulation governing the private relations between the different actors.

\section{The Libertarian Objection to the Duty to Protect}

Certain objections of principle are routinely invoked against the contention that states have a positive duty to protect human rights. The idea that the individual may demand as a human right certain types of legislation from the State, implies that individuals can require certain kinds of conduct of other private individuals. The duty to protect therefore effectively means that human rights can be asserted against other private individuals. It is commonly argued that such a conception of rights is destructive of individual freedom and liberty, because it "requires individuals to be embedded within and committed to a specific social project." ${ }^{59}$ It is argued accordingly that State involvement in engineering and modifying socio-economic arrangements are illegitimate attempts at social engineering or cultural manipulation, aimed at enforcing positive liberties; i.e. freedom "to", rather than freedom "from." ${ }^{60}$ Closely linked to this argument is the strong libertarian notion of the

\footnotetext{
${ }^{58}$ Fourth Report of the Commissioner to the Supreme Court of India in pursuant to People's Union for Civil Liberties v. Union of India and others (Writ Petition [Civil] No. 196 of 2001) (14 August 2003). Available at: http://www.righttofoodindia.org/data/scfour.doc (last accessed 23 November 2010).

${ }^{59}$ Neomi Rao, On the Use and Abuse of Dignity in Constitutional Law, 14 Colum. J. EUR. L. 201, 246 (2008). See, also 221-222: "The socialist aspect of human dignity is also reflected in the positive rights set forth in many modern constitutions... [which] are committed to viewing individual rights within broader social goals and values."

${ }^{60}$ ISAIAH BERLIN, FOUR ESSAYS ON LIBERTY, 1vi (1984): “One freedom may abort another; on freedom may obstruct or fail to create conditions which make other freedoms, or a larger degree of freedom, or freedom for more persons, possible; positive and negative freedom may collide; the freedom of the individual or the group may not be fully compatible with a full degree of participation in a common life, with its demands for cooperation, solidarity, fraternity. But beyond all these there is an acuter issue: the paramount need to satisfy claims of other, no less ultimate values: justice, happiness, love, the realisation of capacities to create new things and experiences and
} 
proper role of the State as being a mere cipher with regards to relations between private individuals. ${ }^{61}$ The most breathtaking example of the "state-as-cipher" mentality can be found in DeShaney v. Winnebago County, where the U.S. Supreme Court held that State child protection authorities were not liable in damages for failing, through negligence, to protect a child that suffered irreparable and debilitating physical harm at the hands of an abusive parent. $^{62}$ Although the state was mandated by statute to prevent such occurrences, the harm, it was held, arose solely from the actions of a private individual, the abusive parent, and not from the State. ${ }^{63}$ The private sphere of action, as the argument goes, is distinct and separate from the public.

A thorough treatment of the incoherence of libertarianism is beyond the scope of this paper. Nevertheless, a few observations may be made. First, some level of social embedding and commitment is clearly needed with respect to specific social projects, such as preventing murders, torture and other serious crimes: individuals can justifiably be required to commit themselves to a system prohibiting such conduct, and we should say that something must be very wrong with a legal system that failed to do so. Indeed, we should say that it was in violation of some very important human rights obligations. ${ }^{64}$ As

ideas, the discovery of the truth. Nothing is gained by identifying freedom proper, in either of its senses, with these values, or with the conditions of freedom, or by confounding types of freedom with one another"

${ }^{61}$ See, e.g. Jackson v. City of Joliet, 715 F.2d 1200, 1203 (7th Cir.), cert. denied 465 U.S. 1049 (1983), per Judge Posner: "The men who wrote the Bill of Rights were not concerned that Government might do too little for the people but that it might do too much to them."

62 DeShaney v. Winnebago County Department of Social Services, (1989) 489 U.S.189 (Blackmun, Brennan JJ. dissenting), $194-203$.

${ }^{63}$ Id. $197-201$.

${ }^{64}$ See, Human Rights Committee, General Comment No. 31, Nature of the General Legal Obligation Imposed on States Parties to the Covenant (CCPR/C/21/Rev.1/Add.13), para. 8, (26 May 2004):

"The positive obligations on States Parties to ensure Covenant rights will only be fully discharged if individuals are protected by the State, not just against violations of Covenant rights by its agents, but also against acts committed by private persons or entities that would impair the enjoyment of Covenant rights in so far as they are amenable to application between private persons or entities."

See, also Committee Against Torture, Hajrizi Dzemajl et al. v. Serbia and Montenegro, Communication No. 161/2000, decision of 21 November 2002, UN Doc. Cat/C/29?D/161/2000, at para. 9.4 (finding a violation of Article 12 of the Convention for failing to carry out a "criminal investigation ... (that) seek(s) both to determine the nature and circumstances of the alleged acts and to establish the identity of any person who might have been involved therein", in the aftermath of a pogrom against the Roma community in Danilovgrad, now Montenegro). States also have a duty to prevent such human rights violations from occurring: see Human Rights Committee, Herrera Rubio et al v. Colombia, Communication No. 161/1983, decision of 2 November 1987 and UN Doc. CCPR/C/OP/2 at 192, (1990), paras. 10.3, 11 (finding a violation of Article 6 ICCPR "because the State party failed to take appropriate measures to prevent the disappearance and subsequent killings of Jose Herrera and Emma Rubio de Herrera and to investigate effectively the responsibility for their murders..." at para. 11) and InterAmerican Court of Human Rights, Velásquez-Rodriguez v. Honduras (Merits), Judgement of July 29, 1988, Series C 
such, there is no universally applicable prohibition on drafting citizens into service for all social projects. But, perhaps it is possible to draw some kind of distinction between the State's regulation of the relations between private persons (where it is under a rightsbased obligation), and its regulation of the general societal conditions that give rise to these private relations.

Rao for instance considers that socio-economic rights are really values and ideals. ${ }^{65}$ She implies that socio-economic rights are really no more than general societal conditions to be desired, and that conflating them with "real" civil and political rights risks trivializing the concept of rights, which is of peremptory "trumps" over all other considerations. This contention may be addressed as follows: rights may generally be understood to correspond to morality, which asks the question: "how should I treat others?" To torture others, for instance, is an abominable way to treat a person, and consequently, individuals have rights not to be tortured. (Of course, rights do not perfectly track the moral question: one does not have a right not to be snubbed in the elevator). The matter of ends or ideals on the other hand, is something we normally explore under the banner of ethics, which asks the questions: "how should I live my life?" or "how should I seek happiness?" Should one spend one's life in religious contemplation, collecting and appreciating great art, or working on a cure for cancer? Rao is correct when she says that a political authority should not dictate conceptions of ethical value to its subjects: it should not for instance impose particular a particular religious outlook on non-believers, nor should it tell homosexuals that they may not seek happiness with those they truly love. Rao is also completely correct in saying that the tendency of using the concept of "dignity" in constitutional law is to conflate these two different questions. ${ }^{66}$ However, this is because the two sets of questions are not completely distinct: it would be a violation of rights/morality to unreasonably deny an individual the chance at pursuing her conception of the good, and equally, it would be impossible to live a truly good life unless one treated others justly. That said, it is clear that having access to a minimum adequate level of food sufficient to live a minimally decent life has much more to do with justice, rather than desirable ends, like the ability to appreciate good art. It is a clear question of justice, especially given the fact the abundance of food that is available.

The theoretical identification of socio-economic rights with values, interests, ideals or ends rather than rights unravels totally, when one notes, as Tushnet does, that "the people or

No. 4, para. 166 (construing the obligation to "ensure" the free and full exercise of Convention rights): "the States must prevent, investigate and punish any violation of the rights recognized by the Convention and, moreover, if possible, attempt to restore the right violated and provide compensation..."

${ }^{65}$ Rao, supra, note 59, 221-222: "The socialist aspect of human dignity is also reflected in the positive rights set forth in many modern constitutions... [which] are committed to viewing individual rights within broader social goals and values."

${ }^{66}$ Id. 222-227. 
corporations exercising "private" power are actually exercising power conferred upon them by laws creating and regulating market behavior. Thus, government is always somehow implicated in private decisions." ${ }^{67}$ Amartya Sen demonstrates this necessity in the context of the right to food: in the last Bengal famine (1943), three million people starved to death despite there being more than enough food to go around, because property and ownership laws allowed traders to hoard grain in order to drive up prices. ${ }^{68}$ In this fashion,

“... market forces can be seen as operating through a system of legal relations (ownership rights, contractual obligations, legal exchanges, etc.). The law stands between food availability and food entitlement. Starvation deaths can reflect legality with a vengeance. ${ }^{69 "}$ (emphasis added)

The State is not a cipher, and neither officials nor citizens can escape moral responsibility for the conditions that support exercises of private relations resulting in clear injustice. Human rights obligations must therefore inform these relations. ${ }^{70}$ As such, the duty to protect should have a number of implications for the development of antitrust and competition laws.

\footnotetext{
${ }^{67}$ Mark Tushnet, The issue of state action/horizontal effect in comparative constitutional law, INT. J. CONSTITUTIONAL L. 79,79 (2003).

${ }^{68}$ DeVeloment AS Freedom, 167. See, generally, $162-170$.

${ }^{69}$ AMARTYA Sen, POVERTY AND FAMINES, 166.

${ }^{70}$ There may be some cavil over my characterisation of competition law as a species of private law, rather than of administrative law. Certainly, competition regimes often contain public enforcement bodies, and competition harm is generally seen as harm to the market as a whole, rather than to one or a few specific undertakings. There are two reasons for my choosing to characterise competition law as a form of private law. First, it would be comparatively easier to formulate the argument that administrative laws and procedures should be cognizant of human rights obligations, and I find that in order to properly counter an argument, that argument has to be put at its strongest. Second, one very influential competition regime, the US, operates to a very significant extent through private litigation.
} 


\section{Rationales For Competition Control of Buyer Power in Food Supply Chains}

\section{Competing Rationales for Competition Law}

The most influential competition and antitrust regimes today primarily concern themselves with 'the protection of the competitive process to ensure an efficient allocation of resources, lower prices and greater consumer choice." ${ }^{71}$ In other words, the main thrust of most competition regimes at present is the protection of the interests of end consumers. For example, Neelie Kroes, the previous European Commissioner for Competition Policy, articulated this position in a speech given in London in October 2005:

"Consumer welfare is now well established as the standard the Commission applies when assessing mergers and infringements of the Treaty rules on cartels and monopolies. Our aim in simple: to protect competition in the market as a means of enhancing consumer welfare and ensuring an efficient allocation of resources." 72

In this way, it is argued that "a basic lesson of the economics of vertical restraints, and exclusionary conduct in general, is that antitrust analysis need only be concerned with the welfare of the final consumer. The end consumer only cares about the quality, quantity, and price of the final product. What transpires upstream in the process of producing the final product is irrelevant to the consumer of the final good." ${ }^{73}$

From the consumer's perspective, buyer power or concentration is generally viewed as a good thing leading to a more efficient allocation of resources; the downward pressure forces less efficient producers to merge, cut their costs, or to exit the market, leaving the field open for more efficient ones. Buyer concentration is especially beneficial if the buyer

\footnotetext{
${ }^{71}$ M. Gangi, Competition Policy and the Exercise of Intellectual Property Rights, LUISS Working Paper 353, 357 (1999).

72 SPEECH/05/512, available at www.ec/europa/eu, (Last Accessed: 19 November 2010). See, also UK Competition Commission, describing competition as "a process of rivalry between firms... seeking to win customers' business over time." Merger References: Competition Commission Guidelines (June 2003, CC 2), para. 1.20; and Market Investigation References: Competition Commission Guidelines (June 2003, CC 2), para. 1.16); U.S. Federal $7^{\text {th }}$ Circuit in University Life Insurance Co. v. Unimarc Ltd., 699 F.2d 846, 853 ( $7^{\text {th }}$ Cir.) (1983) defining competition as "a state in which consumer interests are well-served rather than as a process of rivalry that is diminished by the elimination of even one tiny rival."

${ }^{73}$ Richard Scheelings \& Joshua D. Wright, 'Sui Generis'?: An Antitrust Analysis of Buyer Power in the United States and European Union, 39 AKRON L. REV. 207, 212 (2006).
} 
power essentially acts as a countervailing force against powerful sellers, ${ }^{74}$ or if the cost savings are then passed on to consumers. For the most part, modern competition law generally considers buyer power a positively benign pro-competitive force or, at the very least, a matter of little or no competitive concern. This is demonstrated by the relative paucity of case-law on buyer power; even though buyer power featured prominently among the major concerns of the legislators who promoted the Sherman Act, ${ }^{75}$ it is remarkable to note that the European Courts ${ }^{76}$ - both the General Court (ex Court of First Instance) and the Court of Justice - have not broached the subject even once. The closest thing one can find to a mention of buyer power of the non-countervailing variety in the jurisprudence of the European Courts is the following comment in passing by AdvocateGeneral Maduro in FENIN:

...the existence of a monopsony does not pose a serious threat to competition since it does not necessarily have any effect on the downstream market. Furthermore, an undertaking in a monopsonistic position has no interest in bringing such pressure to bear on its suppliers that they become obliged to leave the upstream market. ${ }^{77}$

It was not always like this (and in some parts of the world, it still isn't). As adverted to in the introduction, many competition tribunals consider buyer power in a much more negative light, based on a theory of competition control that makes a point of protecting certain classes of producers. The most explicit current example of this is the South African Competition Act 1998, section 2 of which aims to "promote and maintain competition in the Republic in order... (e) to ensure that small and medium-sized enterprises have an

${ }^{74}$ Case T-342/99, Airtours v. Commission [2006] ECR II-2585, para. 277 (General Court), Case 322/81, Michelin v. Commission [1983] ECR 3461, para. 73; Case T-228/97, Irish Sugar v. Commission [1999] ECR II-2969, para. 114; Opinion of Advocate-General Mischo, Case C-163/99, Portugal v. Commission [2001] ECR I-2618, para. 106.

${ }^{75}$ Buyer power was in fact one of the primary concerns of the legislators who enacted the Sherman Act, and some of the earliest cases under the Act concerned powerful agricultural buyers: see 21 CONGRESSIONAL RECORD 2461 (1890), statement of Senator John Sherman: "These trusts and combinations . . . operate as a double-edged sword. They increase beyond reason the cost of necessaries of life and business, and they decrease the cost of raw material, the farm products of the country. They regulate prices at will, depress the price of what they buy and increase the price of what they sell." Id. 2457, statement of Representative Taylor: (speaking of "trusts") “... this monster robs the farmer on the one hand and the consumer on the other."

${ }^{76}$ Although the Courts have said very little on the subject, the European Commission has considered buyer power concerns on a number of occasions in its capacity as the merger regulation authority. See, Commission decisions in the mergers of Kesko/Tuko (November 1996) [Commission prohibits merger of two large Finnish chains on the grounds that they would be able to reduce input prices "to an extent that no rival could match", thus precluding new market entry]; Blokker/Toys ' $R$ ' Us (June 1997) [Commission prevents merger of two Dutch toy retailers because market power over suppliers were not complemented by economies of scale in purchasing]; Rewe/Meinl (Feb 1999) [Merger of Austrian food retailers approved with conditions]; Carrefour/Promodes (June 2001).

${ }^{77}$ Opinion of Advocate-General Maduro in Case C-205/03 P, FENIN v. Commission (2005), para. 66. 
equitable opportunity to participate in the economy; and ( $f$ ) to promote a greater spread of ownership, in particular to increase the ownership stakes of historically disadvantaged persons." 78 Moreover, section 12A(3) of the Act on merger control requires consideration by the Competition Commission or Tribunal of whether the proposed merger has an effect on "the ability of small businesses or firms controlled or owned by historically disadvantaged persons to come competitive." Ch. 4, part B of the Act allows the Competition Tribunal to exempt for up to five years otherwise anticompetitive agreements if they, inter alia, promote "the ability of small businesses and or firms controlled or owned by historically disadvantaged persons..." The definition of "historically disadvantaged" persons is provided as those persons "disadvantaged by unfair discrimination on the basis of race" ${ }^{\prime 79}$ before the coming into force of the post-apartheid Interim Constitution of 1993.

Except for that of social redistribution, U.S. antitrust law reflected attitudes and motivations broadly similar to the abovementioned provisions of South African competition law until the Reagan administration. In U.S. v. Von's Grocery Co., the U.S. Supreme Court held that " $(\mathrm{t})$ hroughout the history of these statutes [i.e. Sherman Act] it has been constantly assumed that one of their purposes was to perpetuate and preserve, for its own sake and in spite of possible cost, an organization of industry in small units which can effectively compete with each other." ${ }^{\prime 80}$ Black J. was slightly off the mark in saying that the preservation of small businesses was "for its own sake"; earlier, the Supreme Court had held that the purpose and reason for this legislative stipulation was in order "to yield the best allocation of our economic resources, the lowest prices, the highest quality and the greatest material progress, while at the same time providing an environment conducive to the preservation of our democratic political and social institutions." 81 This ordoliberal conception of antitrust law as providing the "comprehensive charter of economic liberty" 82 began to unravel in the late 1970s in an environment of "rapidly accelerating inflation, lower productivity, and increasingly negative balance of payments, and dramatic advances by Japanese and German producers in world markets...." ${ }^{83}$ Given the need to compete with cheap imports, fears about the nefarious effects of big business upon the integrity of the economy and the political system came to be seen as an unaffordable luxury. ${ }^{84}$

\footnotetext{
${ }^{78}$ South African Competition Act 1998, section 2.

${ }^{79}$ Id. Chapter 1, para. 3, section 2.

${ }^{80} 384$ U.S. 270, $274-75$ n.7 (1966) (Black J.).

${ }^{81}$ Northern Pac. Ry. v. United States, 356 U.S. 1, 4 (1958).

${ }^{82} / d$.

${ }^{83}$ Eleanor M. Fox, The Modernization of Antitrust: A New Equilibrium, 66 CoRnelL L. REV. 1140, 1142 - 43 (1981).

${ }^{84}$ Eleanor M. Fox, Equality, Discrimination and Competition Law, 41 HARVARD INT. L. J. 579, 582 (2000).
} 
An aversion to "bigness" has once again raised its head in popular consciousness, as a result of certain investment banks, despite having brought themselves to (and in the case of Lehman Brothers, beyond) the brink of collapse, claiming billions of dollars of taxpayers' money as a result of being "too big to fail". But professional and academic circles are also cottoning onto the highly destructive effects of bigness. The corrupting influence of big money on democratic processes was also made exquisitely obvious in the recent Citizens United $^{85}$ case, where the U.S. Supreme Court overturned decades of precedent in order to find that corporations and other imaginary persons were endowed with exactly the same rights of expression as real human beings, thus allowing them the unlimited right to contribute to the campaign funds of candidates they favor, or to the opponents of those they disfavor. ${ }^{86}$ Dworkin summarizes these fears in the U.S. context when he observes that

“... money is the curse of our politics. Candidates and political parties collect enormous sums to finance their various electoral campaigns, and this practice corrupts politics and government for several wellrehearsed reasons. Politicians spend grotesquely more effort in raising money than they do on reflecting on policy or principle. Parties made rich by the contributions of great financial interests have an enormous advantage in the competition for votes, and new and poor political organizations are for that reason alone at a usually fatal disadvantage. Large campaign contributors purchase what is euphemistically called "access" to officials; in fact they often purchase not merely access but control. Big money poisons politics in yet another way, moreover, which is often less noticed. It puts enormous sums at the disposal of politicians and their consultants, which makes possible the hugely expensive television and radio campaigns of glitz, slander, and endless repetition of half-truths and pointless factoids that have become the lifeblood of our dumbed-down politics...." ${ }^{\prime 7}$

These concerns by and large have yet to filter into antitrust law, especially in the US, ${ }^{88}$ where consumer welfare protection remains the animating principle. As such, it would appear that modern competition law is indefensible because it is fundamentally at odds with the right to food, in that while the former protects only consumers, the most pressing

\footnotetext{
${ }^{85}$ Citizens United v. Federal Election Commission, 130 S.Ct. 876 (2010).

${ }^{86}$ Ronald Dworkin, The Devastating Decision, The New York Review of Books (25 February 2010). Available at: http://www.nybooks.com/articles/archives/2010/feb/25/the-devastating-decision/ (Last Accessed: 23 November 2010).

${ }^{87}$ Ronald DWorkin, Is Democracy Possible Here? Principles for a NeW Political Debate, 128 - 129 (2006).

${ }^{88}$ If anything, Citizens United shows that the U.S. Supreme Court is at any rate positively embracing an unquestioning acceptance of the benevolence of corporate power, given the "marketplace" concept of the freedom of expression underlying Kennedy J.'s opinion.
} 
obligation arising under the latter is the protection of producers. This statement, however, needs some qualification.

\section{A Consumerist Argument for Control of Buyer Power}

There are objections to buyer power that can be formulated from the perspective of consumer welfare. The most obvious one concerns when the sole or dominant buyer also has considerable market power in the downstream selling market. Conventional economic theory stipulates that the monopsonist (M), in order to maximize profits, will effectively reduce its demand for the input it purchases, and in the process reduce the price that the producers of those inputs obtain. In theory, $\mathrm{M}$ will continue to reduce its demand to the point where the cost to it of suppliers dropping out exceeds the benefits to it of the price savings from the low prices asked for by the seller who remain in the market. Due to the reduction in the amount of inputs, the output produced by $M$ will be similarly reduced. If the downstream selling market is competitive, other producers will make up for $\mathrm{M}^{\prime} \mathrm{s}$ shortfall, and the immediate welfare of end consumers will arguably not be affected. ${ }^{89}$ If, on the other hand, $\mathrm{M}$ is also dominant in the downstream market, the welfare of end consumers will be adversely affected by the diminution in quantity of the end product available, which is compounded by the fact that monopoly sellers tend to depress the quantity of their output in order to maximize their profits. ${ }^{90}$

However, $M$ can, at least in theory, address quite easily the problem of reduced input, through price discrimination and market segmentation. The reason why levels of inputs in the upstream market is reduced is because at the price offered by $M$, some who would otherwise have produced the input, decide not to do so. $\mathrm{M}$ must therefore obtain its inputs from the remaining few who are glad to supply at that low price. If, on the other

\footnotetext{
${ }^{89}$ Some may be curious as to how a producer can wield monopsony or dominant buyer power in its input markets while at the same time having nothing of the sort in its downstream product market. Consider the example of a milk pasteurising plant. The input - fresh milk - is highly perishable, and can be viably transported only over a short range before it becomes unsaleable. As such, if there are no other milk processing plants in within this geographical range, that plant will wield buyer power. However, the end product, pasteurised milk, is much less perishable, and can be transported nationally, or even globally. As such, the plant will not probably have any market power in its downstream market.

90 The compounding of losses to consumer welfare is called "double marginalisation." See, Richard J. Sexton \& Mingxia Zhang, An Assessment of the impact of Food Industry Market Power on U.S. Consumers, 17 AGRIBUSINESS 59 (2001) and rebutting Oliver E. Williamson, Economies as an Antitrust Defence: the Welfare Trade-Offs, 50 AM. ECON. REV. 18 (1966). Whereas Williamson argues that both total welfare as well as efficiency are enhanced where market power increases, Sexton and Zhang show that "only extraordinary increases in efficiency could possibly offset the deadweight welfare loss" the occurs when a firm is has power on both buying and selling markets. $O p$. cit. Peter Carstensen, Buyer Power, Competition Policy and Antitrust: the competitive effects of discrimination among suppliers, 53 ANTITRUST BULL. 271, 283, (note 26) (2008).
} 
hand, it were possible to offer each producer precisely the price he or she were willing to accept in order to begin to produce the input, there would be no reduction at all in the level of input relative to what would obtain in a perfectly competitive market. ${ }^{91}$ The process of offering producers the precise price at which they are willing to begin to supply can be carried out, to varying levels of accuracy, by off-market transactions such as direct contracting where $\mathrm{M}$ deals directly with each supplier or with a group of similarly situated suppliers. ${ }^{92}$ As such, no diminution in immediate end consumer welfare arises as a result of M's monopsony power in its upstream input market.

Leaving aside the obvious interjection that perfect price discrimination (i.e. perfect congruence of M's offer with the price at which each individual seller is willing to begin to produce) is unlikely to occur in practice, such buyer power nevertheless produces important consumer harms, regardless of whether or not $M$ engages in price discrimination. These harms occur, however, only in the long-term. The setting of input prices at precisely the level where suppliers are willing to begin to produce, means that all producer welfare is appropriated by $\mathrm{M}$. Thus, the suppliers may have nothing to set aside for such things as research and innovation, or even the replacement of deteriorating capital equipment. As such, over time, the quality of goods enjoyed by end consumers will decline, as suppliers either exit the market or consolidate, while new entrants are discouraged from replacing them due to the lack of incentive to do so. Where suppliers react to such buyer power by themselves merging and combining, end consumers can expect their choices to diminish.

It has been argued that pure monopsony is exceedingly rare in any market. Rather, it is more common to find that a market is dominated by a few powerful purchasers, and this alters the analysis somewhat. It was stated earlier that monopsonies can be consumer welfare-enhancing if cost savings are passed on to end consumers. ${ }^{93}$ Dominant buyers in food supply chains do not generally seem to do this; instead, cost savings derived from driving down supplier prices tend to be retained by both input processors and end retailers. $^{94}$ One explanation for this phenomenon, especially in the retail sector, is that

${ }^{91}$ Richard Posner, ANTItrust LaW, 79-86 (2001). Posner demonstrates, on the selling side, that a monopoly could produce at the efficient quantity demanded by society instead of at a level below that, if it was able to effectively charge individual buyers a unique price that was proportionately related to their willingness to purchase. Moreover, he identifies this as the real source of the objection to tying and bundling.

92 Carstensen, supra, note 90, 283 - 284. Carstensen observes the use of "all-or-nothing" clauses in various American agricultural markets between buyers and producers, whereby the buyer requires the seller to supply his total production.

${ }^{93}$ See, text pertaining to note 74 .

${ }^{94}$ It may be observed that whereas farm prices for coffee beans fell by $80 \%$ between 1997 and 2002, retail prices for coffee dropped only $27 \%$. At the same time in 2001, Starbucks' and Nestlé's profits rose by $41 \%$ and $20 \%$ respectively: Celine Charveriat, Bitter Coffee: How the Poor are Paying for the Slump in Coffee Prices, Oxfam (16 May 2001); op. cit PAUL RoberTS, THE END OF FoOd: THE COMING CRISIS IN THE WORLD FOOd INDUSTRY 159 (2008). 
when prices rise, retail consumers tend to shop around in search of a better bargain, thus pressuring retailers into raising prices in unison. However, the argument goes, when prices fall, they do not shop around quite so much, leading to less pressure to decrease prices all at the same time. ${ }^{95}$ According to this argument, the cause of price-"stickiness" is not buyer power, but the fact that consumers are willing to settle for a marginally higher price than trudge wearily from one supermarket to another in search of a better bargain. This defense misses the point: surely this is not supposed to happen in a competitive and efficient market, which by definition sends accurate price signals to all parties, including consumers. A market is efficient only if it incentivizes all parties, including end consumers, to act efficiently.

The fundamental lesson to be drawn from this is that excessive appropriation of producer welfare will, in the fullness of time, be detrimental to consumer welfare. An example of this above rationale being applied by competition authorities and tribunals may be found in the UK Competition Commission's regulation of certain abusive practices by large supermarket retailers in the 2008 Groceries Market Investigation. Such practices were held to transfer so much risk and uncertainty to producers that they could potentially have resulted in the abovementioned harms to consumers. ${ }^{96}$ The European Commission has also held that dominant buyers may possess the ability to dictate to consumers the choice of products that come to market, and that the success of product innovations may be dependent largely upon their reactions. ${ }^{97}$

There remains of course, the second limb of Advocate General Maduro's argument for lowballing the importance of competition control of monopsony or dominant buyer power; the expectation that buyers like $M$ will not squeeze their suppliers too much, because $M$ has an interest in maintaining viable sources of supply. The events of the past two years have not inspired confidence in the propensity of, at the very least, the banking sector to self-regulate in accordance with its long-term interests, and nothing particularly distinguishes in this regard them from other private profit-making actors. Indeed, one may suspect that a firm that gets into particular habits of dealing with its suppliers over a long period of time will find it difficult to change them. Again, in the 2008 Groceries Market Investigation, the UK Competition Commission found that of the 52 practices identified in a similar market investigation carried out in 2000 and accordingly listed in the Supermarkets Code of Practice (SCOP), 20 of them were still being practiced eight years later at the time of the 2008 investigation. ${ }^{98}$

\footnotetext{
${ }^{95}$ OECD Policy Roundtable on Competition and Regulation in Agriculture: Monopsony Buying and Joint Selling 8 (2004).

${ }^{96}$ UK Competition Commission, Groceries Market Investigation (2008), para. 9.5, 157.

${ }^{97}$ Case No. IV/M.1221, Rewe/Meinl, Commission Decision, para. 74. (1999)

${ }^{98}$ UK Competition Commission, Groceries Market Investigation (2008), para. 9.63, at 169.
} 


\section{The Consumerist Objection to the Commodity Problem}

The preceding discussion provides some reason why a consumer-welfare oriented competition regime should be concerned about the abuse of dominant buyer power. However, the tendency of many agricultural markets to display the commodity problem might arguably undo the above arguments. Earlier, it was argued that the consumerwelfare problem of buyer power lies in the fact that monopsony buyers depress the supply of inputs because of the low price they offer. ${ }^{99}$ However, to reiterate, the supply of certain commodities, such as coffee, tends to increase in response to a decrease in price, thereby producing a temporary downward price spiral, ending only when the marginal revenue to producers falls below marginal cost, such that sufficient numbers of them leave the market. Regardless of how farmers and producers may fare under this arrangement, it might be argued that buyer power in such instances can work only to the benefit of consumers, because they obtain more coffee at even lower prices.

This conclusion would be premature. It has been reported that since the 1990s, the supply of high quality arabica coffee from Kenya has been replaced to a significant extent with cheaper but lower quality robusto beans from Vietnam. Losses in quality were masked by additional processing by firms further up the supply chains, and the addition of flavorings and sugar. ${ }^{100}$ Although consumers still get their coffee, their range of choice and quality has been reduced. The downward and upward spirals respectively of price and quantity of supply are ultimately unsustainable; the circle ends when producers stop replacing worn out capital equipment and eventually leave the market. For Kenyan coffee farmers, this means the uprooting of entire villages and resettlement in urban slums; for consumers, it means the loss of a high quality brand or product, potentially forever.

A close and detailed examination of the particular types of abusive conduct taken by dominant or monopsony buyers would be beyond the scope of this short paper. Indeed, they appear to be practically unlimited. They range from dominant buyers demanding such large volume discounts that suppliers are obliged to raise prices for other buyers (the "waterbed effect"), ${ }^{101}$ retrospectively adjusting terms of supply to pass on costs and risks

\footnotetext{
${ }^{99}$ See, text pertaining to note 89 .

${ }^{100}$ THE END OF FOOD, $157-158$.

101 See, Paul Dobson \& Roman Inderst, Differential Buyer Power and the Waterbed Effect: Do Strong Buyers Benefit or Harm Consumers? 28 EUR. COMPETITION L. ReV. 393 (2007) and Paul Dobson \& Roman Inderst, The Waterbed Effect: Where Buying and Selling Power Come Together, WISCONSIN L. REV. 331 (2008). As a result of dominant buyers being supplied at lower prices than non-dominant ones, dominant buyers are able to pass on cost savings to end consumers, which only increases the dominant buyer's market share in the downstream market. Thus a vicious circle is set into motion.
} 
to suppliers, ${ }^{102}$ or methods of off-market contracting aimed at reducing transparency in markets. ${ }^{103}$ Some types of abusive conduct, such as the passing on of excessive risks and costs to suppliers, are aimed simply at capturing welfare from producers, while others, such as "waterbedding" and predatory bidding up of input prices, ${ }^{104}$ also have this effect but are designed primarily to exclude the buyer's competitors on both upstream and downstream markets. Hereafter follows a very brief description of the some categories of buyer conduct considered abusive.

\section{Waterbed Effects}

Waterbed effects refer to when a dominant buyer demands from sellers a discount from the market price that reflects the savings made by the seller due to production economies of scale. ${ }^{105}$ This may effectively mean that the dominant buyer alone captures the savings or an inequitably large proportion thereof, such that the seller cannot pass on these savings to other buyers. This then puts the non-dominant buyers at a competitive disadvantage in the downstream market, leading to the acquisition by the firm of dominance on both the buying and selling markets. It should be noted that the disadvantage borne by smaller buyers need not necessarily manifest itself in price increases; they may come in the form of shortages in supply to smaller buyers because of volume purchases by large, dominant ones, or in poorer service by sellers to smaller buyers.

According to the Working Paper on the Waterbed Effect (henceforth Working Paper) the intuitive explanation for the waterbed effect is as the result of a "virtuous circle"106 that is

\footnotetext{
${ }^{102}$ Of the 52 practices investigated by the Commission, 26 were concerned with "practices that have the potential to create uncertainty for suppliers regarding their revenues or costs as a result of the transfer of excessive risks or unexpected costs to suppliers". See, UK Competition Commission, Groceries Market Investigation (2008), para. 9.52, at $166-67$.

${ }^{103}$ Carstensen, supra, note 90, 283-284.

104 Weyerhaeuser Co. v. Ross-Simmons Hardwood Lumber Company, Inc., 549 U.S. 312 (2007)(Thomas J.). The Supreme Court applied to predatory bidding the same test it applies to predatory pricing, as established in Brooke Group Ltd. v. Brown \& Williamson Tobacco Corp., 509 U.S. 209 (1993). Accordingly, it declined to find that the defendant firm had committed a violation of the Sherman Act by bidding up the price of inputs to an extent that its competitors were priced out of the market. Instead, mirroring of its case law on predatory pricing, it required a demonstration of a dangerous possibility that the defendant firm would be able to subsequently recoup the costs incurred by its predatory bidding, at 324 .

${ }^{105}$ Such a "discount" may be an explicit reduction in price, or it may come in the form of passing on to the seller certain costs associated with functions normally carried out by the buyer, i.e. grading of the livestock, stocking of shelves, etc.

${ }^{106}$ Paul Dobson, Exploiting Buyer Power: Lessons from the British Grocery Trade 72 ANTITRUST L. J. 532, 554 (2005). The circle would presumably be vicious from the perspective of small sellers.
} 
caused by some buyers being larger than others. A refusal by a seller to supply would affect a large buyer less than it would affect a small buyer. As such, small buyers are in a worse bargaining position than large ones, and are not able to demand the same low prices extracted by large buyers. These lower input costs will be passed on to the buyer's own customers in the form of lower prices, thus reinforcing the large buyer's competitive edge. As large buyers become even larger (i.e. by retailers opening more outlets), their bargaining power increases, as does their competitive advantage over small buyers. ${ }^{107}$ Accordingly, evidence of a waterbed effect would not be simply a difference in selling prices between dominant and non-dominant buyers, but a tendency by sellers to increase selling prices to non-dominant buyers in response to a discount given to a dominant buyer. No competitive concern is raised if the seller simply refrains from extending the discount to the non-dominant buyers. This pricing strategy would produce exclusionary effects at no short-term cost to the dominant buyer, because that firm will actually be able to acquire its inputs or goods for retail at a cheaper rate thereby. Thus there is no concern raised over the likelihood of recoupment of costs of pursuing the exclusionary strategy, because there are no such incurred costs.

Consumer welfare may be diminished in a number of ways: ${ }^{108}$ for instance, if the downstream market is also sufficiently concentrated, dominant buyers will face less pressure from their competitors, meaning that there will be little incentive for them to pass on cost savings to the end consumer. This means consumers may end up paying an artificially high price. Alternatively, consumer welfare may be diminished if such "waterbedding" results in sellers leaving the market or foregoing investment in capital replacement and innovation. Consumers may thus be left with less choice in products, retail outlets, or lower quality products. ${ }^{109}$

With regard to enforcement, competition law faces a big problem in fashioning effective remedies for such abusive pricing practices of individual firms. Firstly, as may be gleaned from the above discussion, it may be difficult to distinguish an abusive price from a legitimate price extracted by a large buyer on account of its purchasing economies of scale. However, this difficulty should not be exaggerated. The crucial factor should be whether the seller increases costs to small buyers in response to discounts given to large buyers. Moreover, as the Working Paper observes, "buyer size reflects buyer power", ${ }^{110}$ meaning

\footnotetext{
${ }^{107}$ UK Competition Commission, Working Paper on Waterbed Effect (2008), 3-4. Note that the Working Paper was dealing with such effects in the context of retail markets.

${ }^{108}$ Id. 6-7.

${ }^{109}$ Dobson, Exploiting Buyer Power, supra, note 106, 556.

${ }^{110}$ UK Competition Commission, Working Paper on Waterbed Effect (2008), 19.
} 
that measures of market size should be a handy guide as to whether or not there has been an abuse. $^{111}$

Secondly there is the matter of fashioning a remedy. Competition authorities around the world will be rightfully wary of directly setting sale prices. One possible solution would be to ensure that there is only one sale price offered by the seller. This is the approach favored by the U.S. Robinson-Patman Act. ${ }^{112}$ However, the Act places the burden of enforcement in that it places the burden of compliance upon the seller, who is one of the victims of buyer power; it requires that sellers do not offer different prices for identical goods to different buyers. On the other hand, the Act does prohibit inducements to seller discrimination, and it is argued that it may be used to control buyer power accordingly. ${ }^{113}$

\section{Off-Market Contracts Reducing Market Transparency}

To reiterate, the standard problem identified with the tendency of the monopsonist to depress price is the reduction of output by the seller, which in turn reduces the productive capacity of the dominant buyer. One way the dominant buyer may retain prior levels of supply is by adopting an "all-or-nothing" buying strategy. This involves the buyer telling the seller that it requires a minimum total level of output before it will buy anything at all. Whereas the increased production levels demanded of the seller means that economies of scale are exploited, the benefits derived from it are entirely captured by the buyer. Effectively, the buyer obtains a level of supply that would be available only in a competitive market, except without paying a competitive price for it. ${ }^{114}$

Such arrangements are common in many livestock markets, and are especially prevalent in poultry raising markets. Poultry raising contracts involve an exclusive buyer determining the number of chickens to place with each individual farmer, and this will normally coincide with the buyer's needs. ${ }^{115}$ Especially in the context of retail markets, such

\footnotetext{
111 Id. The Working Paper concluded that the "material detriment to UK consumers of groceries" was, "at this stage", likely to be very small, in light of the objections to a number of the assumptions underlying the waterbed argument. It is to be noted that the Commission did not dismiss the argument out of hand, but maintained that it was dependent upon further empirical research, such that it would "continue to analyse suppliers' price data". At 20 .

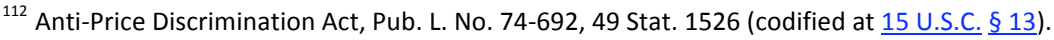

${ }^{113}$ Carstensen, supra, note 90, 329-330.

${ }^{114}$ Id., $283-284$

${ }^{115}$ Randi llyse Roth, Redressing Unfairness in the New Agricultural Labor Arrangements: An Overview of Litigation Seeking Remedies for Contract Poultry Growers, 25 U. MEM. L. REV. 1207 (1995).
} 
contracts tend to result in the seller transferring the higher marginal costs of its increased production to other retailers who do not have buyer power. This contributes to a retail "waterbed" effect. ${ }^{116}$

Also important in this regard are confidentiality clauses, which increase the "switching costs" borne by producers by reducing the amount of transparency in the market. They work particularly to the disadvantage of sellers, by leaving them unable to compare the various options available to them. ${ }^{117}$ The secrecy also allows buyers to set prices differently for different producers. Such clauses are common in contractual relations in livestock markets between select feeders and large meat packers. Increasing transparency in food markets will allow sellers to be able to bargain for more value should they know that other sellers are getting more favorable terms. Moreover, increasing transparency in markets allows disfavored sellers to realize that they are being disfavored, and either adapt so as to remove the feature that leads to the differential treatment, or exit the market. Moreover, the proliferation of confidentiality clauses in individual contracts leads to prices on public markets and commodity exchanges becoming unreflective of the actual demand for the particular input.

At first glance, it may be argued that such contracts are unimpeachable because they do not result in any loss of total welfare. The reduction in producer welfare is simply because it has been appropriated by the buyer. Indeed, it may be argued that such contracts have pro-competitive effects because they result in greater output than if the monopsonist had not insisted on the all-or-nothing clause. This welfare gain may be passed on to end consumers, especially if the downstream market is competitive. The answer to this argument is twofold. First of all, in the short run, the use of all-or-nothing clauses may result in a net loss of total welfare, especially in retail markets, because the dominant buyer who enjoys low prices will not increase his consumption, while the non-dominant buyers who are "waterbedded" are likely to reduce their purchases as a result of higher prices. ${ }^{118}$ Consumer welfare may be adversely affected by excluding the competing nondominant sellers. Secondly, even in input markets, the appropriation of producer welfare also destroys any incentive for the seller to produce, thereby encouraging him to exit the market at the nearest opportunity. In the context of farming, it is clear that such an exit may not be made with ease, since farming communities are often tied to the land by their substantial sunk costs. Instead, the disincentive to continue production will be reflected in a failure to invest in new capital equipment as depreciation occurs, meaning that future production and innovation will be compromised.

${ }^{116}$ See, generally Dobson \& Inderst, Differential Buyer Power, supra, note 101; and Dobson \& Inderst, The Waterbed Effect, supra, note 101.

${ }^{117}$ Carstensen, supra, note 90, at 281.

${ }^{118} / d_{.,} 299$. 
As such, all-or-nothing clauses are in essence a form of price discrimination by the buyer, with the buyer demanding output according to the capacity to supply of each seller. In this wise, an analogy may be made between such off-market contracting methods and "tying" or "bundling" schemes, which are generally prohibited under most competition regimes. Such schemes are prohibited as exclusionary practices, on the theory that they instance a firm using its dominant position in one market to "leverage" itself into a dominant position on another market. ${ }^{119}$ The "waterbed" effect that may be caused by all-or-nothing clauses is analytically identical to such "leveraging", and should therefore be equally prohibited.

Such price discrimination as carried out by off-market contracting methods also effectively privileges some suppliers over others, by giving the former group contracts with better prices than that offered on the open market. Thus, such contracts can be used as to exploit individual sellers, as well as exclude others. However, as highlighted above, price discrimination is objectionable even if there is no exclusionary effect. The same is true of tying and bundling agreements. By, for example, bundling ink cartridges to the sale of its printers, a dominant printer manufacturer could effectively charge its customers a price reflective of their demand for the printer. This would effectively allow the seller to appropriate all consumer welfare. Richard Posner argues that this is the true ground of the objection to tying and bundling, because it remains true even where the "leveraged" market is not remotely capable of being monopolized. ${ }^{120}$ It is acknowledged that the above objection, translated to the context of all-or-nothing clauses, reduces producer welfare rather than consumer welfare, which is the main (or even sole) concern of most competition regimes. However, as also demonstrated above, the appropriation of producer welfare will have adverse effects upon consumer welfare in the long run.

The use of "all-or-nothing" clauses for the purposes of ensuring the buyer's supply may have a particularly pernicious effect with respect to food security and the right to food. Should adverse weather conditions result in a poor harvest, the presence of such a clause may oblige farmers to set aside more land for the growing of the sale crop, rather than on the production of food, thereby tipping the area into famine. It has the effect of orienting farm production excessively towards sale and/or export. According to Carstensen, such contract clauses do not present much of an enforcement problem for competition law. He argues that one can set out with comparative ease theories as to why such all-or-nothing contracts are harmful to competition. The remedy may come in the form of a simple injunction or a regulation prohibiting buyers from buying other than in set quantities, and requiring them to accept tenders from all potential sellers. ${ }^{121} \mathrm{~A}$ caveat must be made to

${ }^{119}$ See, e.g. U.S. v. United Shoe Machinery Corp., 391 U.S. 244 (1968); Case T-30/89, Hilti AG v. Commission (General Court); Case C-333/94 P, Tetra Pak International SA v. Commission, [1996] ECR I-5951 (ECJ); Case T201/04, Microsoft Corp v. Commission, [2007] 5 CMLR 11 (General Court).

${ }^{120}$ Posner, supra, note 91, 234-238.

${ }^{121}$ Carstensen, supra, note $90,318$. 
this general rule for "contract farming", where buyers provide other valuable consideration to farmers such as access to cheap credit and other inputs. ${ }^{122}$ In these cases, there is more scope to say that buyers are properly compensating producers.

\section{Retrospective Adjustments to Terms of Supply}

In retail markets, suppliers make investment decisions based on variable market conditions. All decisions are made by estimating the likely returns and balancing them against the risks involved by that particular course of conduct. Retail buyers on the other hand, have strong incentives, given the stressful nature of the sales market, to pass excessive risks and unexpected costs onto their suppliers. Such conduct will have the effect of capturing excessive supplier welfare, thereby removing seller's incentive to invest in capital equipment and innovation. ${ }^{123}$ According to the UK Competition Commission, retrospective adjustments to the terms of supply are the primary means by which excessive appropriation of producer welfare is facilitated. ${ }^{124}$

\section{Stocking/slotting fees and "Category captainship" agreements}

Retailers may increase the price of access to their shelves and thereby transfer wealth from sellers to retailers by charging sellers a fee for stocking their products. Moreover, in retail markets, the practice of appointing "category captains" goes one step further by making such captains in charge of managing their particular category. Managerial costs are effectively transferred from the retailer to the seller.

\section{E. Implications of the Duty to Protect upon Competition laws}

As demonstrated above, a plausible argument can be made for the curtailing of buyer concentration and power in agricultural markets, from the standpoint of consumer welfare protection alone. To reiterate, the consumer harms arising from certain types of dominant buyer conduct may manifest only in the long-run, and until that time, remain

\footnotetext{
122 De Schutter, Agribusiness Report, supra, note 24, 17, paras. $43-45$.

${ }^{123}$ UK Competition Commission, Groceries Market Investigation (2008), paras. 9.41 and 9.46, 164.

${ }^{124}$ Of the 52 practices investigated by the Commission, 26 were concerned with "practices that have the potential to create uncertainty for suppliers regarding their revenues or costs as a result of the transfer of excessive risks or unexpected costs to suppliers". See, UK Competition Commission, Groceries Market Investigation (2008), para. 9.52 , at $166-67$.
} 
indeterminate or vague. This raises some questions about the propriety of competition control in the present, given that the goal of attaining efficient, competitive markets is undermined by excessive regulation, just as much as it is by under-regulation. Accordingly, competition regimes generally require a showing of identifiable and likely harms to consumer welfare before they will prohibit the conduct complained of as an abuse of a dominant position. ${ }^{125}$

Admittedly, it can be argued, again, from consumerist premises alone, that this caution is misplaced when it comes to controlling buyer power because the consumer harms arising from abuses of buyer power are at any present moment incalculable. Consider the above example of the Kenyan coffee producers. The harm to consumer welfare caused by the decline in production of arabica beans was somewhat offset by coffee houses turning to robusto beans produced by Vietnamese farmers, the consequent decline in quality being offset to some extent the development of a process artificially to improve the flavor of robusto coffee, as well as by the new practice of adding various flavorings and sugar. ${ }^{126}$ It might very well have turned out that the Vietnamese could not have provided cheaper robusto beans for sale, or that consumers would have not cared for such highly processed products. The fact that both the Vietnamese coffee farmers and consumers did what they did was highly unforeseeable from the outset. Accordingly, the harms are also profoundly unforeseeable. Therefore, a strict insistence upon a showing of specific harms will hobble the ability of competition regimes to prevent a whole category of consumer harms: those harms manifesting in the long-term. Moreover, it should be observed that legal systems have never shied from addressing harmful conduct just because those harms are incalculable at present. Where damage is incapable of being reduced to monetary terms, equitable or in personam remedies are traditionally awarded. Indeed, the use of competition controls to prevent the occurrence of presently unquantifiable future harms occurs regularly in merger regulation. The EU Commission for instance, has on many occasions prohibited mergers and combinations from occurring where they would have resulted in the creation of dominant positions in purchasing markets. ${ }^{127}$

Some may counter, assuming the existence of credible merger regulation, that it should suffice for competition control of abuses of dominance to apply only when consumer harms arising from buyer power reach some adequate level of "ripeness". This would be inadequate. By the time the consumer harms manifest themselves in higher prices and reduced choice and quality, too many producers may have left the market or consolidated in order for competition remedies to have any corrective effect. In other words, it may be

\footnotetext{
${ }^{125}$ Philip Marsden, Microsoft v. Commission - With Great Power Comes Great Responsibility, COMPETITION LAW INSIGHT 3, 4 (October 2007).

${ }^{126}$ THE END OF FOOD, $157-158$.

${ }^{127}$ See, supra, note 76 .
} 
far too late to do anything. To take the example of the Kenyan arabica coffee bean farmers mentioned above, it is reasonably clear that the consumer harms of higher prices and reduced availability of high quality arabica coffee will obtain only after significant numbers of producers have or consolidated, or left the market altogether (i.e., left their mountain villages and settled in towns). It is, at the best of times, difficult in the extreme to undo mergers. It is even more difficult to entice former coffee farmers to return to their villages. Instead, end consumers will be saddled with the consequences.

Accordingly, a purely consumer welfare-oriented competition regime could, in light of the above considerations, adopt a preventative approach to abuses of buyer power, and the remedies proposed should be prophylactic in nature. An important example of this more enriched conception of consumer harm in application may be found in the UK Groceries Market Investigation (2008), where the UK Competition Commission held that it was authorized to find an "Adverse Effect on Competition" (AEC) without having to "identify specific harm to the interests of" consumers. ${ }^{128}$

However, both EU competition law and US antitrust appear to have set their respective faces against such prophylaxis. Under an abuse of dominance analysis per Article 102 TFEU (ex Article $82 \mathrm{EC}$ ), the difficulty lies in showing a "detrimental effect upon trade" within the $\mathrm{EU}$, which is taken to mean an adverse effect upon consumers. We are thus returned to the opinion of Advocate General Miguel Poiares Maduro in FENIN. In this regard, Carstensen notes that the advantage of using $\S 1$ of the Sherman Act (prohibiting anticompetitive agreements) is that it requires far less of a showing of market power than would be required under $\S 2$ (establishing the monopolization offence). Moreover, it would allow courts to be able to use a Microsoft ${ }^{129}$ analytical framework while relying on the smaller threshold of market power allowed under $\S 1^{130}$ (the provision which prohibits cartelisation, and whose equivalent in EU law is Article 101 TFEU (ex Art. 81 EC)). As per the analysis in Microsoft, the question of whether such an agreement is anti-competitive or abusive may be answered in the affirmative if (1) the plaintiff or competition authority is able to show harm to competition (not just competitors) in both theory and fact (2) the defendant firm is either unable to show that there is a legitimate business justification for its conduct; or (3) the plaintiff is able to show that the reasons put forward by the

\footnotetext{
${ }^{128}$ UK Competition Commission, Groceries Market Investigation (2008) para. 7, Appendix 2.2, 2.

${ }^{129}$ Microsoft v. U.S., 253 F.3d 34, $58-59$ (D.C. Cir.)(1999)

${ }^{130}$ Carstensen, supra, note 90, 322-23. See, U.S. v. Visa U.S.A., Inc., 344 F.3d 229 ( $2^{\text {nd }}$ Cir.) (2003), where the court held that dominant credit card issuers had unreasonably refused to allow participating banks to join other credit card networks.).
} 
defendant are mere pretexts, or that the same pro-competitive business reasons could have been accomplished by less anti-competitive means. ${ }^{131}$

Given that most of the kinds of conduct identified as abusive, such as all-or-nothing contracts and waterbedding schemes, are generally concluded between buyers and their upstream suppliers, the obvious category of competition or antitrust law under which they may be classified is that of vertical agreements. It must be noted that Courts are generally reluctant to scrutinize such agreements, because it is thought that such practices are generally welfare-improving. ${ }^{132}$ Indeed, many vertical combinations provide procompetitive benefits such as the avoidance of duplication, the eradication of double profit margins, etc. For this reason, US courts will not control such agreements as a restraint of trade under $\S 1$ of the Sherman Act absent a showing that the party benefiting from the restraint possesses market power. Roughly the same rationale lies behind the regulation setting out a Block Exemption for Vertical Restraints in EU Competition law. Admittedly, the current Regulation 330/2010 on Vertical Restraints is an improvement on the nowexpired Regulation 2790/99. ${ }^{133}$ The expired Regulation established a "safe harbor", or presumption of legality for certain vertical agreements depending on the market share of the supplier or buyer and the nature of the vertical restriction, which, when interpreted according to the European Commission's Vertical Restraints Guidelines, ${ }^{134}$ (setting out the Commission's interpretation of the regulation - not binding upon the EU's courts but nevertheless extremely influential) stipulated that the market share of the buyer is considered only if the vertical restraint concerned contained an exclusive supply obligation. Moreover, the safe harbor was available for buyers with a market share of up to $30 \%$. Regulation 2790/99 expired in May 2010. The new regulation, as interpreted by

\footnotetext{
${ }^{131}$ Such an "economic approach" to the determination of abuses of dominant positions under Art. 102 TFEU (ex Art. $82 \mathrm{EC}$ ) has not filtered through the whole of the EC. The EAGCP Consultation Paper, An Economic Approach to Article 82 (July 2005), questioning the prior practice of holding certain activities as per se abusive and disregarding possible pro-competitive effects, is not a binding legal authority, as is the Commission's discussion paper on the application of Art. 102 TFEU (December 2005). At present, only the Commission adheres to an economic approach to Art. 102 TFEU; the General Court and the ECJ appear to remain wedded to the legalistic approach. See, Case T-340/03, France Télécom SA v. Commission and Case T-201/04, Microsoft Corp v. Commission (General Court), as well as Case C-95/04, British Airways v. Commission (ECJ). It is submitted that the economic approach is preferable from a purely theoretical point of view. However, proving harm to competition may be very difficult, especially if it is as remote and indirect (as may be the case in all-or nothing contracts), meaning that in practice, there is the danger of under-regulation if one takes the economic approach.

${ }^{132}$ But note that there is an important school of thought that argues that vertical restraints should be investigated only where the producer wields market power: see e.g. Barbara A. White, Vertical Restraints in Antitrust Law - a Coherent Model, 26 ANTITRUSt BULl. 327 (1981); Frank H. Easterbrook, Vertical Agreements and the Rule of Reason, 53 ANTITRUST L. J. 135 (1984).

${ }^{133}$ Commission Regulation 2790/99, OJ [1999] L 336/21, [2000] 4 CMLR 398. Expired 31 May 2010.

${ }^{134}$ Commission Notice, Guidelines on Vertical Restraints, OJ [2000] C 291/1, [2000] 5 CMLR 1074, para. 21.
} 
the new Commission Guidelines, ${ }^{135}$ provides for the buyer's market share to be relevant where it "purchases the contract goods or services which determine the applicability of the block exemption." ${ }^{136}$ This is a marked improvement even upon draft versions of the new guidelines, which considered the buyer's market share only where it resells the goods or services, or if those goods are inputs into the buyer's own product. ${ }^{137}$ However, the buyer market share threshold for the "safe harbor" remains the same at $30 \%$. Moreover, the latest guidelines set out set out a de minimis market share threshold of $15 \%$, ${ }^{138}$ under which the transaction is presumed to have no effect on trade within the common market. The inadequacy of this is clear when one observes that the UK Groceries Market Investigation of 2000 found that retail grocers with as little as $8 \%$ of the total retail market had substantial buyer power over sellers. ${ }^{139}$

Therefore, competition regimes driven purely by consumer welfare concerns simply do not go far enough. One thing should be made clear at this point; the consumer interests that are protected by consumer welfare-driven competition regimes do not derive from the right to food. Consumers do not have a human right to enjoy arabica coffee now and forever; they are not unjustly injured or diminished if they must content themselves with robusto instead. Such an eventuality, though no doubt disagreeable, neither reduces them to hunger, nor robs them of physical and economic access to adequate food. Those consumer interests merely coincide with the protection of the right to food of coffee farmers in Kenya, whose right to food is thereby violated.

\section{Conform-Interpretation}

One means by which consumerist competition laws could reflect the interface between consumer interests and the demands of the right to food, would be by interpreting rules of competition law in conformity with the right to food. Such conform-interpretation should result in lowering or modifying the de minimis and appreciability thresholds identified above, which are in place because consumers suffer only negligible harm below those thresholds, even though they may have profound effects for producers. A second important effect of conform-interpretation would be the reinforcement of the consumerist argument for controlling buyer conduct despite a lack of presently identifiable consumer

135 Commission Notice, Guidelines on Vertical Restraints, Brussels, SEC (2010) 411. Available at: http://ec.europa.eu/competition/antitrust/legislation/guidelines vertical_en.pdf.

${ }^{136}$ Id. para. 23.

${ }^{137}$ Draft Commission Notice, Guidelines on Vertical Restraints, para. 23.

${ }^{138}$ Id. paras. $8-11$.

${ }^{139}$ UK Competition Commission, Groceries Market Investigation (2000), para. 2.458. 
harm. The UK Competition Commission's claim to be empowered to find an AEC is at present only justifiable with reference to some kind of precautionary principle. ${ }^{140}$ Conforminterpretation with the right to food would reduce or remove the need for reliance on this principle, which has come in for considerable criticism from a number of quarters ${ }^{141}$ because, once again, the welfare of consumers is no longer the sole end to be pursued.

In another sense, including right to food considerations may figuratively "tip the scales" in favor of prevention. According to international human rights law, the duty to protect does not come into operation only when it is beyond doubt that State intervention will prevent human rights violations. In E. and Others v. United Kingdom, ${ }^{142}$ the European Court of Human Rights had to examine whether the UK was liable to the child victims of their mother's partner who had confessed to indecently assaulting them. He was sentenced to two years probation on the condition that he not reside in the family home, but this condition was never adequately enforced by the local authorities. As a result, he returned to the family home, leading to further sexual abuse against the applicants. The Court rejected the UK government's argument that liability could be found only if it was proven that State intervention would definitely have prevented the human rights violation (which, in this case, was Article $3 \mathrm{ECHR}$, on the right against torture and inhuman and degrading treatment). ${ }^{143}$ Instead, it found that "the test under Article $3 .$. . does not require it to be shown that "but for" the failing or omission of the public authority ill-treatment would never have happened. A failure to take reasonably available measures which could have had a real prospect of altering the outcome or mitigating the harm is sufficient to engage the responsibility of the State." ${ }^{144}$ Of course, the above test applies to the civil and political right against torture rather than to socio-economic rights such as the right to food. However a difference in treatment would be difficult to explain without recourse to saying

\footnotetext{
${ }^{140}$ See, Cass Sunstein, Irreversible and Catastrophic, 91 CORNELL L. REV. 841 (2006). The precautionary principle, or various expressions thereof, is found in a number of legal and policy instruments and pronouncements, both domestic and international: e.g. Bergen Ministerial Declaration on Sustainable Development in the ECE Region, U.N. Econ. Comm'n for Europe, Bergen, Noway, 8 - 16 May 1990; UN Conference on Environment and Development, Rio Declaration on Environment and Development, princ. 15, U.N. Doc. A/CONF.151/26/Rev.1 (Vol. I) (1 January 1993); San Francisco, California Environment Code, Chapter 1, section 101, etc. Sunstein posits that there are a number of precautionary principles: namely the Irreversible Harm, Catastrophic Harm and Hazardous Precautions varieties. The argument made by the UK Competition Commission appears to be most akin to the Catastrophic Harm variant, which essentially states that where "risks have extremely bad worst-case scenarios, it makes sense to pay special attention to those risks, even if they are unlikely to come to fruition, and even if existing information does not enable regulators to make a reliable judgment about the probability that they will occur." At 846.

${ }^{141}$ Id.

${ }^{142}$ Application No. 33218/96, (2002).

${ }^{143}$ Id. para. 99.

${ }^{144}$ Id.
} 
that there is a hierarchy of rights, or that civil and political rights are qualitatively more important than socio-economic ones, both of which contradict the principle of the interdependence and indivisibility of the two sets of rights. ${ }^{145}$

It must be observed that the argument for conform-interpretation with the right to food proceeds from entirely different premises than the ordoliberal principle of democracyprotection described earlier, although such concerns could possibly be accommodated under this second human rights-compliant conception of competition law. Certainly, both conceptions of competition law can be described as concerned to different extents with the promotion of rights and the empowerment of classes of persons systematically and consistently deprived of the equal opportunity to participate in society. ${ }^{146}$ The evil identified and addressed by the latter is not the corruption of democratic processes through the influence of big money, but the deprivation of basic minimum levels of individual welfare as a result of market failures. It rests on the simple notion that there is nothing special about consumers that gives them a moral right to the lowest prices possible, ${ }^{147}$ even at the cost of producers' ability to earn an income sufficient to enable them to function as equal members of society.

However, there is the objection that human rights protections should be pursued under other forms of regulation, rather than built directly into competition laws. At present, some very influential voices on this issue argue that human rights requirements and other extraneous considerations are properly the business of other departments and authorities for the reason that competition authorities are simply not equipped with the tools or

${ }^{145}$ See, Recitals 2 and 3 of the common preamble to the ICESCR and ICESCR; General Comment No. 3, supra, note 47:

In this regard, the Committee reaffirms that the rights recognized in the Covenant are susceptible of realization within the context of a wide variety of economic and political systems, provided only that the interdependence and indivisibility of the two sets of human rights, as affirmed inter alia in the preamble to the Covenant, is recognized and reflected in the system in question.

and General Comment No. 9.: The domestic application of the Covenant, UN Committee on Economic, Social and Cultural Rights, HRI/GEN/1/Rev.7, para. 10 (12 May 2004):

The adoption of a rigid classification of economic, social and cultural rights which puts them, by definition, beyond the reach of the courts would thus be arbitrary and incompatible with the principle that the two sets of human rights are indivisible and interdependent.

${ }^{146}$ Eleanor M. Fox, Antitrust and Regulatory Federalism: Races Up, Down and Sideways, 75 N.Y.U. L. REV. 1781, 1798 (2000); Eleanor M. Fox, The Modernization of Antitrust: A New Equilibrium, 66 CORNELL L. REV. 1140, 1151 52 (1981).

${ }^{147}$ See, RONALD DWORKIN, LAW'S EMPIRE, 286-288 (1986). 
expertise to include socio-economic rights concerns in their deliberations. ${ }^{148}$ For instance, Yane Svetiev notes that

"... it is not clear how a court can implement and balance the various potentially legitimate considerations within the framework of an antitrust case. The old [ordoliberal] antitrust rules were over-inclusive and path dependent because in an adjudicative context antitrust cases present a zero-sum game (whereby conduct is declared legal or illegal), and because judicial reasoning is backward looking and yet it has a precedential effect in other market settings. A court cannot regulate the competitive process, which is ongoing by definition, through one-off interventions adjudicating upon a particular practice.Once the need to go beyond broad and over inclusive rules of prohibition is accepted, antitrust decision making must balance context specific considerations...it is unhelpful to insist that antitrust traditionally embodied civic or democratic values other than economic efficiency, unless those values can be translated into rules that guide decision-making in particular cases."

There is much to this argument, in that a simple calculation of incomes and food prices at any point in time, or even over a period of time is not enough to tell us whether all individuals are free from hunger or have physical and economic access to a minimum adequate amount of food. A famous example of this is Amartya Sen's "missing women", i.e. the women who are born but who mysteriously do not make it to adulthood in societies such as South Asia, West Asia, North Africa and China. ${ }^{150}$ Sen states that this phenomenon "has to be analyzed with demographic, medical, and social information, rather than in terms of low incomes, which sometimes tell us rather little about the phenomenon of gender inequality." ${ }^{151}$ Karen Kong remarks that food programs distributing parcels to households have not solved the problem of the relative deprivation of women, because ambient cultural mores and traditions give men more importance than women. ${ }^{152}$ Addressing issues of intra-household allocation of food would almost certainly be beyond the capabilities of competition authorities. These concerns, it may legitimately be argued, fall under the remit of other policy and regulatory institutions, and not competition regimes.

${ }^{148}$ Yane Svetiev, Antitrust Governance: The New Wave of Antitrust, 38 LOYOLA U. CHI. L. J. 608 (2007).

${ }^{149}$ Id. 608-609.

${ }^{150}$ See, Amartya Sen, Missing Women (1992) BRITISH MEDICAL JouRnAL 304.

${ }^{151}$ DeVElopment As Freedom, 20.

${ }^{152}$ Karen Kong, The Right to Food for All: A Right-Based Approach to Hunger and Social Inequality, 32 SUfFoLK TRANSNAT'L L. REV. 525, 533, 552 (2009). 
But it is possible to run too far with this argument: if households in such communities are making absolutely too little income, one can be sure that not just women but also the men are being denied their right to food, and one would be entitled to infer also that the women are being subjected to more egregious deprivations than the men. Can such determinations be made competently by competition authorities? Certainly. If competition authorities can consider themselves adequately qualified to pronounce upon the effect of buyer conduct upon the future sustainability of food supply to consumers, there should be no concern over their ability in assessing whether producers are being deprived of a minimum level of income congruent with the right to adequate food, especially since the former is contingent upon the latter. The core argument of this section is this: while competition authorities need not take on the task of policing child labor, they may and should be concerned about whether such practices arise from the structure of the market. Competition authorities should display a basic curiosity about the causes of such phenomena.

Lastly, there is the requirement of "clear rules" that Professor Svetiev correctly recognizes as being necessary to any kind of judicial function. Whereas "harm to democracy" can perhaps be described as being perhaps too nebulous a quantity for judges to work with, human rights, even socio-economic ones, are not. The ever-growing corpus of socioeconomic rights jurisprudence attests to this. Moreover, an assessment of human rights implications will not produce rigid, per se axioms such as those supposedly derived from ordoliberal antitrust theory. Whereas the content and meaning of the right to food is necessarily constant and therefore path dependent, the rules regarding market conduct can be as fluid as the "ongoing" competitive process. For instance, off-market contracting need not be automatically judged illegal if, as is indeed the case, ${ }^{153}$ it does not deprive individuals of the right to food. As for the enforcement of such human rights-inspired competition rules, it is clear that individual impoverished smallholders may not have the wherewithal to bring suit. But, for that matter, neither do most individual consumers. Public competition commissions generally fill this role on their behalf. There is no reason why human rights protection may not be carried out adequately by public antitrust and competition enforcement institutions, even the FTC, DoJ, or the European Commission.

Moreover a total split between departmental responsibility for competition control and human rights protection would lead in practice to problems of vertical incoherence

\footnotetext{
153 Individual agricultural contracts can indeed be pro-competitive and advance human rights simultaneously if the buyer makes available to smallholders credit facilities to be used for buying equipment, fertiliser, etc; technical advice, and other equitable conditions, such as predetermined prices, minimum income, and penalty clauses for default by buyers: De Schutter, Agribusiness Report, supra, note 24, 17. Essentially, the buyer is paying for his added security of supply. See, also Spencer Henson, Oliver Masakurea and David Boselie, Private food safety and quality standards for fresh produce exporters: the case of Hortico Agrisystems, Zimbabwe, 30(4) FOOD POLICY 371 (August 2005); On the risks inherent in contract farming, see PETER D. LITTLE AND MICHAEL J. WATTS, LIVING under Contract: Contract Farming and Agrarian Transformation In SUb-SaHARAN Africa (1994).
} 
between different ministries not unlike that faced by the Indian Supreme Court in PUCL. John Ruggie's business and human rights framework rejects for these reasons such a "narrow approach to managing the business and human rights agenda", under which many governments place the related issues of competition and regulation into separate "conceptual and (typically weak) institutional box(es)" which then do not communicate with each other ${ }^{154}$.

One obvious means by which the duty to protect may be acquitted would be by specifying through positive legislation the liabilities and responsibilities persons should bear with respect to one another, which derive out of their respective human rights. ${ }^{155}$ There is much to recommend this view, in that persons both natural and legal, should be able to know with sufficient certainty what they may or may not do to other persons. Moreover, it perhaps provides to some extent the "clear rules" Professor Svetiev calls for. However, the quality of clarity can be exaggerated. Tushnet asks us to consider a consumer fraud litigation where a purchaser paid for a car, but it transpired that the item had no engine when it was delivered. Or, that it traveled two blocks before falling apart. We need to consider, "did the vendor comply with his obligation to supply a car?"156 Private law obligations are not immune to the necessity of interpretation, and courts in jurisdictions adhering to the public/private distinction often refer to constitutional or human rights principles as sources of inspiration in carrying out this task. ${ }^{157}$ Indeed, competition law is unusually suited to this method of "conform-interpretation" given that the legislative provisions are necessarily phrased in exceptionally broad and vague terms. Indeed, in the case of EU law, even the more specific regulations require interpretive guidelines by the

\footnotetext{
${ }^{154}$ Ruggie, supra, note $46,8$.

${ }^{155}$ See, $X$ and $Y v$. The Netherlands, judgment of 25 March 1985, Series A, No. 91 (ECHR): “although the object of Article 8 is essentially that of protecting the individual against arbitrary interference by public authorities, it does not merely compel the State to abstain from such interference: in addition to this primarily negative undertaking, there may be positive obligations inherent in an effective respect for private or family life.... These obligations may involve the adoption of measures designed to secure respect for private life even in the sphere of the relations of individuals between themselves (...) the protection afforded by the civil law in the case of wrongdoing of the kind inflicted on Miss $Y$ is insufficient. This is a case where fundamental values and essential aspects of private life are at stake. Effective deterrence is indispensable in this area and it can be achieved only by criminallaw provisions; indeed, it is by such provisions that the matter is normally regulated.

${ }^{156}$ Tushnet, supra, note $67,96$.

${ }^{157}$ See, the Lüth judgment of the German Constitutional Court, 7 BVerfGe 198 (1958) (held that while the primary purpose of basic rights is to protect individuals against public power, the German Basic Law also established "an objective order of values" that must be considered as a fundamental constitutional decision affecting all spheres of law.); and the Supreme Court of Canada in Retail, Wholesale \& Department Store Union, Local 580 v. Dolphin Delivery Ltd. [1986] 2 SCR 573 (Mclntyre J.) (holding that while the rights contained in the Canadian Charter of Fundamental Rights and Freedoms would not invalidate rules of judge-made common law at issue in private litigation, courts ought nevertheless to apply and develop the principles of the common law in a manner consistent with Charter values).
} 
European Commission, ${ }^{158}$ and there is every reason to refer to human rights norms in this interpretive task. A recent opinion issued by Advocate General Sharpston before the European Court of Justice points logically to this end:

"The Court has held that the International Covenant on Civil and Political Rights (ICCPR) is one of the international instruments for the protection of human rights of which it takes account in applying the general principles of Community law. It seems to me that the same should hold good for the ICESCR which, like the ICCPR, binds each individual Member State." ${ }^{159}$

\section{Beyond Conform-Interpretation}

Of course, there are a number of inadequacies in the "conform-interpretation" model. First, the interface of consumer welfare and the right to food may not be perfect. For example, we may imagine a situation where abusive buyer practices completely extirpate the farming of a certain crop in a certain area, but the buyer is able to replace the lost source of supply with an alternative which, at any rate, costs the consumer no more than did the old source, and in all other material qualities is exactly the same. The producers' right to food may have been violated, but it simply cannot be said that consumers are adversely affected to an appreciable extent, even factoring in lower thresholds of presumption as a result of conform-interpretation with the right to food. The limitations of conform-interpretation should become particularly evident in the following section on the "extraterritorial reach." There will also be limits to the ability of judges and competition authorities to conform-interpret the facts to achieve at a result that favors the right to food, and any attempt to go beyond this will be unseemly. Secondly, and more fundamentally, the right to food should be valuable for its own sake, rather than as a means to the end of consumer protection. Kant's second categorical imperative is not just a philosophical jaunt devoid of practical consequence - "dignity" is now recognized as a legal concept in numerous international and constitutional instruments. ${ }^{160}$ The solution of

${ }^{158}$ See, Philip Marsden \& Simon Bishop, Editorial: Intellectual Leaders Still Need Ground to Stand On, 3.2 EuR. COMPETITION J. 315, 315 (2007): reporting that the Judge Cooke of the EU General Court (formerly the Court of First Instance) stated that "I tell my clerks that these cases are 20 percent fact, 20 percent law, and 60 percent policy".

${ }^{159}$ Opinion of Advocate General Eleanor Sharpston, Case C-73/08, Nicolas Bressol and Others and Céline Chaverot and Others v. Gouvernement de la Communauté française, para. 136 (25 June 2009).

${ }^{160}$ See, e.g. Article 1, German Basic Law: ("Human dignity is inviolable”); Sec. 1, Constitution of the Republic of South Africa 1996: ("The Republic of South Africa is one, sovereign, democratic state founded on the following values: (a) Human dignity, the achievement of equality and the advancement of human rights and freedoms..."); Art. 1, European Charter of Fundamental Freedoms: ("Human dignity is inviolable. It must be respected and protected.") 
course, is to recognize that the protection of the minimum level of producer welfare that is demanded by their right to food is itself a proper task of competition law.

Certainly, it is beyond debate that competition authorities may not positively violate human rights by, say, conducting unauthorized dawn raids into offices and the homes of company executives, ${ }^{161}$ or issuing unduly vague summonses or orders. ${ }^{162}$ However, competition authorities, as organs of the State are also required, under the duty to protect, to constrain private corporate conduct that results in the deprivation of the rights of others. As usual, South Africa, whose constitution provides both for the protection of the right to food ${ }^{163}$ and for the horizontal application of constitutional rights, ${ }^{164}$ provides the most fertile ground for this argument. For example, the South African Human Rights Commission (SAHRC), in submissions to the South African Competition Tribunal in proceedings against a bread manufacturer who had participated in a cartel and a drugs manufacturer, called upon the Tribunal to take account of the effect of the controverted market practices upon the right to health and the right to food respectively. ${ }^{165}$

\footnotetext{
${ }^{161}$ Case 37971/97, Société Colas Est v France and others (2002) ECHR III-135 (European Court of Human Rights) (Article $8 \mathrm{ECHR}$ infringed by France as a result of inspectors entering applicant's property without a prior judicial warrant); Cases 46/87, Hoechst AG v Commission [1989] ECR 2859, [1991] 4 CMLR 410, (ECJ) para. 19: “... in all the legal systems of the Member States, any intervention by the public authorities in the sphere of private activities of any person, whether natural or legal, must have a legal basis and be justified on the grounds laid down by law, and, consequently, those systems provide, albeit in different forms, protection against arbitrary or disproportionate intervention.".

162 Woodlands Dairy (Pty) Ltd and Anor v. Competition Commission, (88/CACMar09) [2009] ZACAC 3 (26 September 2009) Competition Appeal Court (South Africa) (unduly vague search warrant); Glaxo Wellcome (Pty) Ltd Others v D. Terblanche Others (03/CAC/Oct00) [2001] ZACAC 2 (5 September 2001) Competition Appeal Court (South Africa) (unduly vague order by lower Competition Tribunal).

${ }^{163}$ Section 27(1)(b) of the South African Bill of Rights: "Everyone has the right to have access to ... sufficient food and water..."

${ }^{164}$ Section 8(1) of the South African Bill of Rights: providing that private persons may be fixed with obligations under the Bill of Rights "if, and to the extent that, it is applicable, taking into account the nature of any duty imposed by the right."

${ }^{165}$ South African Human Rights Commission, Submission to the Competition Commission South Africa in the Matter of the Competition Commission, Tiger Brands Limited and Adcock Ingram Critical Care (Pty) Ltd, Case no. $15 / C R / F e b 07$. The bread manufacturer, Tiger Brands subsequently settled with the Commission, but another member of the cartel, Pioneer Foods, was found liable and fined 195 million rand: Competition Commission v. Pioneer Foods (Pty) Ltd., Case nos. (15/CR/Feb07) (50/CR/May08), reasons issued (3 Feb 2010). I am grateful to Dr. Christine Jesseman for providing me these references.
} 


\section{F. Extraterritorial Reach}

Modern food supply chains are truly global, cutting across countless state and national boundaries. It is not uncommon for salmon to be fished off the coast of Alaska, brought to China for filleting, and transported back to California for sale to end consumers. ${ }^{166}$ The extraordinary amount of concentration at certain strategic points along food supply chains only serves to emphasize the level of interconnectedness between consumers and producers scattered across different parts of the world. As such, some reconsideration of the rules of personal and subject-matter jurisdiction and comity that govern their extraterritorial reach will also be necessary.

\section{Consumer welfare-based theories of jurisdiction}

Significant differences obtain between the practice of antitrust and competition authorities in the US and the EU on the subject of extraterritorial competition law jurisdiction. US Courts established very early on that they had the jurisdiction to control conduct outside US borders but which nonetheless created effects within it. In the celebrated Alcoa decision, Judge Leaned Hand held that it "is settled law... that any State may impose liabilities, even upon persons not within its allegiance, for conduct outside its borders which has consequences within its borders which the State reprehends; and these liabilities other States will ordinarily recognize." ${ }^{167}$ However, subsequent legislative and judicial developments effectively limited the scope of such jurisdiction. These included §6a of the Foreign Trade Antitrust Amendment Act (FTAIA) of 1982, which provided that territorial jurisdiction could be established only where extraterritorial conduct had "direct, substantial and reasonably foreseeable effect" on trade or commerce in the US, and the judgment in Hartford Fire Insurance, ${ }^{168}$ limiting antitrust control to conduct that "was meant to produce and did in fact produce some substantial effect in the United States".

There is considerable uncertainty over the scope of the extraterritorial application of US Antitrust law at present, but a leading case by the US $9^{\text {th }}$ Circuit Court of Appeals in US $v$. LSL Biotechnologies (US v. LSL) ${ }^{169}$ interpreted U.S. law on antitrust jurisdiction to mean that jurisdiction cannot be asserted over foreign conduct that produces only remote effects on consumers in the US. That case involved a contract clause imposed by the defendant U.S.

\footnotetext{
${ }^{166}$ Michael Pollan, The Food Issue - An Open Letter to the Next Farmer-in-Chief, New York Times (12 October 2008).

${ }^{167}$ United States v. Aluminum Co. of America (Alcoa) 148 F 2d 416, (2d Cir.) 444 (1945).

${ }^{168}$ Hartford Fire Insurance Co., v. California, 509 US 764 (1993).

${ }^{169}$ United States v. LSL Biotechnologies, 379 F.3d 672 (9th Cir.)(2004).
} 
corporation upon Hazera, a foreign supplier-developer of tomato seeds, preventing it from supplying any other buyer in the U.S. The U.S. argued, amongst other things, that the clause "makes less likely possible innovations from Hazera in the creation of heartier tomato seeds 'that will allow consumers to enjoy higher quality, better tasting winter tomatoes and that will allow United States farmers to grow long shelf-life tomatoes'." Judge Tallman, writing for the majority, rejected this argument, stating that the "delay of possible 'innovations' does not have a direct effect on American commerce." 170

Clearly, this line of reasoning renders impossible control over conduct of dominant agribusiness buyers in foreign countries on a rationale of consumer welfare protection, because, as mentioned in the main text, the harms to consumers from such conduct, which includes a reduction of capital replacement similar to the decline in innovation in US V. LSL, occurs only in the long-run and indirectly.

In contrast, one may consider the practice of the European Court of Justice in the Wood Pulp ${ }^{171}$ case, where it established objective territorial jurisdiction on the basis that a concerted practice between several non-EU undertakings begun outside of the EU had been implemented in it. Another example of the EU's more expansive approach to assertion of jurisdiction is Gencor v. Lonrho, ${ }^{172}$ where the Court held that application of the EU's merger laws to two South African mining companies was "justified under public international law when it is foreseeable that a proposed concentration will have an immediate and substantial effect in the (Union)". The court however interpreted the criterion of "immediacy" to pertain not so much to economic effects, but to the structure of the market: "the concentration would have had the direct and immediate effect of creating the conditions in which abuses were not only possible but economically rational". ${ }^{173}$ As for the criterion of substantiality, it was not necessary for the "substantial" effect to be immediately discernible: the creation of a duopoly in world platinum and rhodium markets as a result of the merger would only occur in the "medium term", but the scale and importance of that prospect was sufficient to justify assertion of jurisdiction. ${ }^{174}$

The extraterritorial reach of EU competition law is so broad that some commentators have termed it not a new "implementation" doctrine of jurisdiction, but a revival of the original

\footnotetext{
${ }^{170}$ Id., paras. $45-46$.

${ }^{171}$ Case 114/85, Ahlström Oy v. Commission [1988] ECR 5193 (Wood Pulp) (ECJ).

${ }^{172}$ Case T-102/96, Gencor Ltd. v. Commission [1999] II-753 (General Court).

${ }^{173} / d$., para. 94.

${ }^{174}$ Id. paras. $96-98$.
} 
Alcoa "effects" doctrine in its full strength. ${ }^{175}$ Certainly, there is the concern of principle that "an unlimited acceptance of extraterritorial jurisdiction based on economic effects could clearly lead to extensive interference in the internal affairs of other States." ${ }^{176}$ However, this principle of EU competition law has over time gained widespread acceptance, and raises little complaint today. As such, if the concentration and abuse of buyer power domestically results in consumer harm, as I have argued, there should be no reason in practice why conduct occurring overseas which nevertheless has similar effects on domestic consumers should go untouched.

\section{The extraterritorial reach of the right to food: jurisdiction under ICESCR}

Oddly, a number of factors indicate that a human rights-inspired competition law might have less extraterritorial applicability than a consumerist competition law. This arises as a result of the state-centric paradigm that governs contemporary human rights protection. As Narula notes, the ICESCR is unique among international human rights treaties in not stipulating a jurisdiction clause. ${ }^{177}$ Nevertheless, the ESR Committee in General Comment No. 12 defined the jurisdictional scope of the right to adequate food by stipulating that "(e)very State is obliged to ensure for everyone under its jurisdiction access to the minimum essential food which is sufficient, nutritionally adequate and safe, to ensure freedom from hunger." ${ }^{178}$ Also declarative of the relevant general doctrines are the Maastricht Guidelines on Violations of Economic, Social and Cultural Rights, which state

\footnotetext{
175 Olivier De Schutter, Extraterritorial Jurisdiction as a tool for improving the Human Rights Accountability of Transnational Corporations, Background Paper for Seminar organised in collaboration with UN High Commissioner for Human Rights, Brussels, 23, (note 93) (2006) and Andreas Löwenfeld, International Litigation and the Quest for Reasonableness, 33-41 (1996); Derek W. Bowett, Jurisdiction: Changing Patterns of Authority over Activities and Resources, 7 (1982). Moreover, De Schutter notes that "In their joint separate opinion to the judgment of 14 February 2002 delivered by the International Court of Justice in the Case concerning the Arrest Warrant of 11 April 2000 (Democratic Republic of the Congo v. Belgium), Judges Higgins, Kooijmans, and Buergenthal seem to share this reading of developments in European Union law."

${ }^{176}$ P.M. Roth, Reasonable Extraterritoriality: Correcting the 'Balance of Interests', 41 INT. COMP. L. Q. 267, 285 (1992).

${ }^{177}$ Narula, supra, note 34, $728-729$.

${ }^{178}$ General Comment No. 12, supra, note 35, para. 14. The ESCR Committee has used a similar formulation for a number of other rights under the Convention: See, U.N. CESCR, General Comment No. 4: The right to adequate housing, 7th Sess., para. 13, U.N. Doc. E/1992/23 (1992); U.N. CESCR, General Comment 13: The right to education, 21st Sess., paras. 6(a), (b), U.N. Doc. E/C.12/1999/10 (1999); U.N. CESCR, General Comment No. 14: The right to the highest attainable standard of health, 22d Sess., paras. 12(b), 51, U.N. Doc. E/C.12/2000/4 (2000); U.N. CESR, General Comment No. 15, U.N. Doc. E/C.12/2002/11 (2003), paras. 12(c), 31, 44(b), 53; U.N. CESCR, General Comment No. 8: The relationship between economic sanctions and respect for economic, social and cultural rights, 17th Sess., para. 10, U.N. Doc. E/C.12/1997/8 (1997); U.N. CESCR, General Comment No. 9: The domestic application of the Covenant, 19th Sess., para. 9, U.N. Doc. E/C.12/1998/24 (1998).
} 
that responsibility for violations of ICESCR rights is imputable to the state within whose jurisdiction they occur. ${ }^{179}$ (The Maastricht Guidelines consist of the agreed opinions of the International Commission of Jurists, and therefore have no legal binding force. Nevertheless, they are an influential reference point with regards to the ICESCR).

To wit, the concept of jurisdiction is not restricted to the national territory of the state concerned, but extends to foreign territory over which the state exercises "effective control". ${ }^{180}$ The concept of "effective control places two different stumbling blocks preventing the assertion of competition controls for the benefit of the right to food of foreign persons situated overseas. The first is the fact that the sort of influence a state may have over foreign persons through its competition law simply does not amount to "effective control." In Bankovic v. Belgium, the European Court of Human Rights found that Belgium, as a participant in the NATO coalition that bombed Belgrade during the Kosovo crisis, was not responsible for the deaths that occurred as a result of the mistaken targeting of the Radio-Television Serbia tower, on the basis that the NATO members did not exercise "effective control" over the territory. The Yugoslav government was the sovereign entity exercising such effective control at all material times. Likewise, it simply cannot be said that the governments of the States in whose territory the anti-competitive conduct occurs ever relinquished or lost effective control over that territory. A second stumbling block may lie in what appears to be a downplaying of the importance of socioeconomic rights as compared to civil and political rights. In its advisory opinion on the Legal Consequences of the Construction of a Wall in the Occupied Palestinian Territory, the International Court of Justice explained the lack of a jurisdictional stipulation in the ICESCR as arising from "the fact that this Covenant guarantees rights which are essentially territorial." ${ }^{181}$ As De Schutter notes, this "assertion is made without any justification grounded either on the text of the Covenant or on the preparatory works." ${ }^{182}$ One could go further, and say that the ICJ got it exactly wrong: as almost all the discussion in this paper demonstrates, "territoriality" is the one thing that does not characterize contemporary global food supply chains and their implications for the right to food. It is therefore suggested that that case can provide only very little guidance on the right to food, because although it specifically raised the issue of the impact of Israel's building a wall upon the

\footnotetext{
${ }^{179}$ U.N. ESOCOR, Maastricht Guidelines on Violations of Economic, Social and Cultural Rights, 24th Sess., U.N. Doc E/C.12/2000/13, para. 16 (2000).

${ }^{180}$ See, e.g. ECHR cases of Loizidou v. Turkey, 23 Eur. H.R. Rep. 513, para. 52 (1996); Bankovic v. Belgium and Others, App. No. 52207/99, Eur. Ct. H.R. (2001); Issa and Others v. Turkey, App. No. 31821/96, Eur. Ct. H.R. (2004); Ilascu v. Moldova and Russia. American Convention on Human Rights case of Coard et al. v. U.S., Case 10.951, Inter-Am. C.H.R., Rep. No. 109/99, para. 37 (1999).

${ }^{181}$ Advisory Opinion, Legal Consequences of the Construction of a Wall in the Occupied Palestinian Territory, I.C.J. 136, para. 112 (2004).

182 Olivier De Schutter, International Human Rights Law. Cases, Materials, References, 124 (2010).
} 
right to food of Palestinians, it declined to elaborate upon the positive duties Israel would have regarding their vindication, or of the vindication of their social and economic rights in general. $^{183}$ Instead, the most charitable construction we can put on the case is that the court limited itself to Israel's negative obligations. ${ }^{184}$

As such, in the absence of any other jurisdictional hook, the efficacy of a human rightsbased competition law would be limited to purely intra-national or intra-regional food supply chains. To reiterate, modern food supply chains are global. Moreover, in many of the countries where the majority of smallholders producing for those chains live, the state of competition control leaves much to be desired. First, competition control requires "extraordinarily sophisticated domestic institutions (Competition Authorities), backed by legislation, jurisdiction and quasi-judicial independence," ${ }^{185}$ which may be costly for some developing countries. ${ }^{186}$ Second, there may not be the political will on the part of developing countries to challenge the dominance of the largest actors controlling international agricultural markets. This is compounded by the fact that there are at present around 2,500 Bilateral Investment Treaties (BITs) allowing investors to take States to binding international arbitration for changes in domestic law that result in losses to them, where such national legislation was intended to advance social and environmental goals. Such BITs routinely include "economic stabilization" provisions, and/or deem regulatory takings as de facto expropriations of investor property. ${ }^{187}$ These clauses have profound chilling effects on states wishing to embark on any programme of socially progressive legislation, not just competition law. In this regard, territorial theories of jurisdiction are patently in dire need of change. The doctrine of "effective control" of territory needs to be amended to one of "effective economic control" ${ }^{188}$ in order to catch up with the already at least twenty year-old phenomenon of globalization. Professor Sornarajah develops this line of thought when he finds that "developed States owe a duty of control to the international community and do in fact have the means of legal control over the conduct abroad of multinational corporations." 189

${ }^{183}$ Legal Consequences of the Construction of a Wall, para. 112.

${ }^{184}$ Narula, supra, note 34,734

${ }^{185}$ Markus W. Gehring, Sustainable Competition Law, Conference Paper for the 2003 Fifth Session of the Ministerial Conference of the World Trade Organisation, 2 (Cancun, Sept. 10-14, 2003).

${ }^{186}$ Taimoon Stewart, Julian Clarke and Susan Joekes, Competition Law in Action: Experiences from Developing Countries, International Development and Research Centre, 26-41 (2007).

${ }^{187}$ Ruggie, supra, note 46 , at 5 . Prof. Ruggie provides by way of example a recent instance where a European mining company challenged South African laws meant to advance the economic standing of black citizens. See, Piero Foresti, Laura de Carli and others v. Republic of South Africa, International Centre for the Settlement of Investment Disputes, case no. ARB (AF)/07/1.

${ }^{188}$ Narula, supra, note $34,734$.

${ }^{189}$ M. SORNARAJAH, The INTERNATIONAL LAW ON FoREIGN INVESTMENT, 169 (2004). 
There are, however, some cracks in this general scheme. In General Comment No. 14 on the right to health, the ESCR Committee held that:

“... States parties have to respect the enjoyment of the right to health in other countries, and prevent third parties from violating the right in other countries, if they are able to influence these third parties by way of legal or political means, in accordance with the Charter of the United Nations and applicable international law." ${ }^{190}$

Interestingly, the UN Human Rights Committee, in considering the practice of refoulement, has held it would be "unconscionable" to interpret responsibility under human rights instruments as to "permit a State Party to perpetrate violations [...] on the territory of another State, which violations it could not perpetrate on its own territory." ${ }^{191}$ Certainly, the same objections can be rehearsed that these pronouncements apply to civil and political rights, rather than to socio-economic rights, etc, etc, and the same rejoinders can be made to those objections. However, I would like to consider the implications of not extending the above principles to the right to food, and to the competition regimes that must be interpreted by their light. If the duty to protect human rights is to be limited to the State's territory, then there will have to be two sets of competition law: a human rights compliant one for one's own nationals, and a human rights non-compliant one wherever producers are located overseas. Apart from adding to the already considerable consternation of the students of the subject, officials and diplomats will be pressed to explain why there are, in effect, two bodies of competition law, of which one permits violations of the human rights of the individuals it affects. It is one thing to deny certain rights to foreigners which derive from citizenship of the State, but it is quite another, to deny them their human rights.

\footnotetext{
${ }^{190}$ U.N. Committee on Economic, Social, and Cultural Rights, General Comment No. 14: The Right to the Highest Attainable Standard of Health (Article 12 of the International Covenant on Economic, Social and Cultural Rights), U.N. Doc. E/C.12/2000/4, para. 39 (2000). It is not entirely clear whether this obligation arises under its duty to protect the human rights of all individuals under its jurisdiction, or whether it is one of international cooperation, which I will explore in the subsequent section.

${ }^{191}$ HRC, Delia Saldias de Lopez Burgos v Uruguay, Comm. No. 52/1979, paras. 12.1-12.3 (29 July 1981); Lilian Celiberti de Casariego v. Uruguay, Comm. No. 56/1979, para 10.3 (29 July 1981). The ECtHR, on the basis of the HRC pronouncements, has concluded that: "Article 1 of the Convention cannot be interpreted so as to allow a State party to perpetrate violations of the Convention on the territory of another State, which it could not perpetrate on its own territory" in Issa a. o. v. Turkey, Appl. No. 31821/96, para. 71 (16 November 2004) and Isaak v. Turkey (Dec.), Appl. No. 44587/98, para. 19 (28 September 2006) and Solomou v. Turkey, Appl. No. 36832/97, para. 45 (24 June 2008) and Andreou v. Turkey (Dec.), Appl. No. 45653/99, 10 (03 June 2008) and AlSaadoon and Mufdhi v. United Kingdom (Dec.), Appl. No. 61490/08, para. 85 (30 June 2009). I am grateful to Violeta Moreno-Lax for these references.
} 


\section{International Cooperation}

There is, however, one means by which developed consumer states can extend the benefit of human rights-based competition laws to the developing states where the majority of impoverished small farmers live. Article 2(1) ICESCR requires States to implement the right to food and all other rights contained in the Covenant "individually and through international assistance and cooperation." ${ }^{192}$ This precise language is repeated in Article 11(2) ICESCR concerning the measures to be taken by States Parties, and Article 11(1) ICESCR provides that "States Parties will take appropriate measures to ensure the realization of this right, recognizing to this effect the essential importance of international co-operation and comply with their commitment to take joint and separate action to achieve the full realization of the right to food." Additionally, the Committee has noted that the obligation of international cooperation "is particularly incumbent upon those States which are in a position to assist others in this regard." ${ }^{193}$

Accordingly, there may be a legal obligation for developed states to offer assistance to developing ones to defray the costs of maintaining and staffing credible competition authorities, and for developing countries to accept such assistance. Such assistance may come from the United Nations Conference on Trade and Development (UNCTAD) which offers technical training courses on competition law and policy to judges, enforcementofficials and other decision-makers from developing countries with respect to adopting, maintaining and improving national competition law systems. ${ }^{194}$ Other methods of advancing growth of competition law in developing countries would be to adopt International Cooperation Agreements by which States parties agree to assist each other with respect to producing and exchanging documentary evidence, and even to apply the other country's competition laws where appropriate. ${ }^{195}$

Although international cooperation is phrased as a legal obligation, it suffers from an indeterminacy of the extent and scope of the obligation, let alone ways of enforcing it. Essentially, it is an attempt to impose some legal order over the dark lawless tracts of foreign policy, where diplomats habitually "trade in State prestige and advantage, not in

\footnotetext{
${ }^{192}$ Article 11(2) ICESCR.

${ }^{193}$ General Comment No. 3, supra, note 47, para. 14.

${ }^{194}$ TD/RBP/CONF.5/7/Rev.3, Model Law on Competition, United Nations Conference on trade and Development, United Nations (“UNCTAD Model Law”), Section E, paras. 7 - 9 (2007); Section F, paras. 6 \& 7, which provide for the exchange of competition expertise between states, the setting up and financing of courses under the aegis of the UN. See, also the UNCTAD website on training courses offered in Geneva or by correspondence: http://www.unctad.org/Templates/Page.asp?intltemID=4116\&lang=1 (Last Accessed : 23 November 2010).

${ }^{195}$ See, the Closer Economic Relations Agreement, entered into force between Australia and New Zealand on 1 January 1983.
} 
justice." ${ }^{196}$ However, the argument has been made that the obligation of international cooperation is part of an emerging recognition of states' "duty to fulfill" the rights of persons who are neither citizens nor within its jurisdiction, ${ }^{197}$ and this can be situated within the emerging awareness of how human rights have significance even outside the state-centric paradigm. Put simply, the previously vague and nebulous obligation of international cooperation is being sharpened and defined into something justiciable. An example of this may be found in General Comment No. 15 on the right to water, where the ESCR Committee held that:

"International cooperation requires States parties to refrain from actions that interfere, directly or indirectly, with the enjoyment of the right to water in other countries. Any activities undertaken within the State party's jurisdiction should not deprive another country of the ability to realize the right to water for persons in its jurisdiction., ${ }^{198}$

\section{Deeper Questions of Principle: Political Legitimacy}

At this point, the reader may observe that the fundamental argument of the above scheme is that States must vindicate the rights of persons other than their own citizens. Insofar as those arguments are based on the duty to protect and the duty to fulfill, the reader might be positively alarmed at the necessary implication that non-nationals may demand as of right that one's State implement certain measures to ensure physical and financial access to a minimum adequate level of food in other countries. It may be objected, that notwithstanding any moral duties, States cannot justifiably be held to any such legal obligations regarding the right to food to individual non-nationals outside their jurisdictions. If so, the statements made by myself and by others in the immediately preceding section must appear naïve and/or utopian, and the above cited positive "legal" pronouncements wrong and illegitimate.

The response to this objection will have to be brief and impressionistic: this small essay cannot begin to expound a legal, moral, and/or political theory on the subject of what obligations States owe to outsiders given that it has been treated by figures no less illustrious than Kant and Rawls, ${ }^{199}$ whose works are by no means the last word on the

\footnotetext{
${ }^{196}$ GeOfFrey Robertson, The Justice GAME, 98 (1998).

${ }^{197}$ Fons Coomans, Some Remarks on the Extraterritorial Application of the International Covenant on Economic, Social and Cultural Rights, in Extraterritorial ApPlication of Human Rights Treaties, 196 (Fons Coomans \& Menno Kamminga eds.)(2004).

${ }^{198}$ General Comment No. 15, supra, note 178, para. 31.

199 See, immanuel Kant, Perpetual Peace, (1795); John Rawls, The LaW of Peoples (1999).
} 
subject. We may begin by asking why it is important to protect human rights at all purely within the territorial confines of the State. If we disregard communitarian and popular sovereignty-based theories of legitimacy, we find there is, in general, a broad consensus among liberals that respect for certain fundamental human interests - described variously as equality, liberty, or the all-encompassing term of "dignity" - is the basic condition that must be fulfilled by the State, or any other form of polity, in order for it to be entitled to moral authority over its subjects. A failure to show such respect releases those subjects from any bond or obligation of loyalty; for instance, "the apartheid government of South Africa had no legitimate authority over blacks." ${ }^{200}$ This is generally what is meant by assertions that all men are created equal, that they are endowed with certain inalienable rights, that the sole end of government is to secure these rights, and that whenever "any Form of Government becomes destructive of these ends, it is the Right of the People to alter or abolish it...."201

These are not simply political or philosophical speculations, but often legal ones as well, since adjudication is required in order to ascertain which kinds of disrespect entitle individuals to which kinds of resistance. In a fascinating, recent advisory opinion the Supreme Federal Tribunal of Brazil recently had to consider as a legal issue the concept of political legitimacy with respect to a challenge to the constitutionality of a general amnesty law. ${ }^{202}$ The Federal Bar Council of Brazil applied for an opinion on the constitutionality of a general amnesty law which suspended investigations into torture allegedly carried out by officials of the former right-wing government. It was argued that the amnesty was incompatible with Brazilian constitutional protections against torture, and that investigations should therefore be resumed. Proponents of the amnesty law argued that if proceedings were brought against former officials, similar ones would have to be instituted against former left-wing insurrectionists as well. In rebuttal, it was argued that no such proceedings could be brought because their resistance was against an illegitimate government.

\footnotetext{
200 IS DEMOCRACY POSSIBLE HERE, 97.

201 US DECLARATION OF INDEPENDENCE, (1776).

202 Supreme Federal Tribunal, Statement of Breach of Fundamental Provision [Arguição de Descumprimento de Preceito Fundamental (ADPF)], N 153, Judgment [Acordão] 29 April 2010. Applicant: Federal Bar Association of Brazil [Conselho Federal Da Ordem Dos Advogados Do Brasil], on the reach of the Brazilian amnesty Law (Law No. 6.683/1979)(Brazil). Available

at:

http://www.stf.jus.br/portal/jurisprudencia/listarJurisprudencia.asp?s1=\%28153.NUME.+OU+153.ACMS.\%29\%28 PLENO.SESS.\%29\&base=baseAcordaos (Last Accessed : 23 November 2010). I am grateful to Matthias Sant'ana for this reference.
} 
However, these theories of political legitimacy pertain only to the "sovereign people,"203 and leave unanswered the question of those people from whom the State does not extract allegiance. Why should a State not be free to mistreat outsiders, as a matter of law, if it does not obtain any benefit or forbearance from those outsiders in return? One could say that a State that mistreats outsiders invites sanctions from other States, but this is an argument of reciprocity and self-interest rather than a normative one of law or morality. ${ }^{204}$ At any rate, this option is not available as regards a State too militarily or financially powerful to be sanctioned effectively. Are we then to say that States owe absolutely no human rights duties to outsiders, and that nothing they can do to those outsiders can affect their legitimacy?

Although it has yet to be comprehensively explored and theorized, there is an ancient and powerful conviction that a polity which is sufficiently cruel to outsiders effectively forfeits its right to exist. ${ }^{205}$ We retain this conviction to this day when we say that it is wrong for, say, States to allow "enemy combatants" to be detained and tortured in overseas military bases, or to allow planes to carrying individuals for extraordinary renditions to land on one's territory, even though the torture will be carried out by others in faraway places. Such conduct not only provides outsiders with a dispensation to interfere or undermine the concerned political system, but also provides the citizens of that political system a reason to disrespect its directives. If one accepts this premise, it becomes possible to accept, as legal in character, the pronouncements of the ESR Committee purporting that States must not facilitate violations of the rights to food and water on foreign soil. We deny the legality of these pronouncements only at the cost of denying that extraordinary rendition and indefinite definition of enemy combatants are illegal.

Once again, we may encounter the argument that socio-economic rights such as the right to food are simply different from civil and political rights such as the right not to be tortured. The only additional comment to be made outside what has already been said in Part C, Section III of this paper is to consider the effect of a denial of the right to food upon the legitimacy of State. To the contention that subversion from within and interference from without may be justifiable in the case of widespread torture or genocide, but that it cannot be justifiable as against a State that simply fails to distribute its food properly, ${ }^{206}$ one may point to histories of famine such as Mark Davis' Late Victorian Holocausts, which

\footnotetext{
203 Allen Buchanan \& Robert Keohane, The Legitimacy of Global Governance Institutions, 20(4) ETHICS AND INT. AFFAIRS 405, 416 (2006).

204 Daniel Bodansky, The Legitimacy of International Governance: A Coming Challenge for International Environmental Law?, 93 AM. J. INT. L. 596, 600 (1999).

${ }^{205}$ Genesis 19:8 - 19:9 [destruction of Sodom and Gomorrah].

${ }^{206}$ This is where I part company from Rawls. See, LAW OF PEOPLES, 75 - 78, which considers as a minimally "decent" society, one which refrains from persecuting minorities and which observes due process of law.
} 
leave one with the strong suspicion that the vast majority of mutinies and insurrections that have taken place in history have resulted not from religious oppression or racial discrimination, but famine. One would be hard pressed to argue that these uprisings were illegitimate.

With respect to the extraterritorial application of socio-economic rights, a much more knotty problem is raised by the concept of equality. Rawls famously noted as one of the limbs of his Theory of Justice that the priority had to be given to liberty, because equality is a political value that is shared only to those within one's own political community, and at that, only in public life. ${ }^{207}$ For instance, we do not generally give non-citizens a vote in public elections. $^{208}$ We even make leeway for despicable kinds of discrimination in this regard: a bigot is not required to invite to her birthday party members of the ethnic or religious community they despise, nor are churches required to conduct marriage services for gay couples. Various scholars identify equality solely with the quality of sovereignty, ${ }^{209}$ understood as the monopoly on force. If equality is available only within the State, Nagel asks, "how can we begin to conceive of global justice?"210

Of course, one solution would be to bring the entire world under one sovereign government, but this is indeed utopian, and in the bad sense. More modest goals such as the development of a world antitrust authority have met with failure. There was an attempt to create an international competition court in the Havana Charter 1948, which served as the foundation for the General Agreement on Tariffs and Trade (GATT). Chapter $\mathrm{V}$ of the Charter dealt with restrictive business practices, and also required State parties to regulate anticompetitive activities of an international nature. ${ }^{211}$ However, because of ratification difficulties in the US, Chapter V was left out of the GATT. On the other hand, it has proved impossible to separate competition issues from trade matters ${ }^{212}$ and accordingly, the WTO Working Group on the Interaction between Trade and Competition

${ }^{207}$ See, generally JOHN RAWLS, A THEORY OF JUSTICE (2005) and JUSTICE AS FAIRNESS (2001).

${ }^{208}$ An interesting exception to this general rule is found in Part 1 of the UK Representation of the People Act 2000 (c.2), which provides that Commonwealth and Irish citizens may vote in Parliamentary elections [section 1(c)], and in elections for local government [section 2(c)]. It appears to be a gesture of contrition for centuries of colonial rule.

209 Ronald Dworkin, The Sovereign ViRTUe, 6 (2002) and Thomas Nagel, The Problem with Global Justice, 33(2) PHIL. \& PUB. AFFAIRS 113, 126 (2004).

${ }^{210}$ Nagel, supra, note 208, $130-133$.

211 Article 46(1), Havana Charter, available at: http://www.wto.org/English/docs_e/legal_e/havana_e.pdf (Last Accessed: 23 November 2010)

${ }^{212}$ Robert D. Anderson \& Hannu Wager, Human Rights, Development, and the WTO: the cases of intellectual property and competition policy, 9 J. INT. ECON. L. 707, 736 (2006). 
Policy (WGTCP), formed at the Singapore Ministerial Conference in 1996 has been active in formulating a "multilateral framework on competition policy." ${ }^{213}$ These developments at the WTO however, appear to address the competitive problem of cartelisation rather than on abuse of dominance, thereby missing the point, at least where the purpose of this article is concerned. ${ }^{214}$ One should be under no illusions about the political impossibility of creating a world international court.

Nor will it do to declare that "we possess human rights by virtue of our humanity", or even, as Sen puts it, that "if one is in a position to do something effective in preventing the violation of [human rights], then one does have a good reason to do just that - a reason that must be taken into account in deciding what should be done. It is still possible that other obligations, or non-obligational concerns, may overwhelm the reason for the particular action in question, but the reason is simply not brushed away as being 'none of one's business'."215 Justice indeed appears to be best understood as an associative virtue, and the correct default position is that you are not required to ensure that your neighbor's children are as well-fed, clothed and educated as your own: one may legitimately care more for one's own.

Instead, the solution to Nagel's query may very well be to proceed from this premise. When then do you actually come under an obligation to do something about the neighbor's children? Two instances come to mind. The first is when those children are in such a perilous condition, and you are so relatively well-off that it would not harm you in the least to help them. You disgrace yourself when, ensconced in silken cushions on your verandah, you see the child starving to death outside and do nothing. This humanitarian duty corresponds, roughly to the aspect of the right to food described as the right to be free from hunger. The second is when the condition of those children is the result of something you have done to them. If you have burned down their house, it is your moral duty, to compensate them, or, at the bare minimum, to desist from doing it again. Such assistance as you may give, is not charity, but a moral obligation. This obligation, which corresponds to the right to adequate food, transcends the community over which one ordinarily shares the sovereign virtue of equality.

There is one last problem. It may be said that the example above, of when one falls under duties to one's neighbour, presumes that we do not live in a Hobbesian State of Nature. Instead, it presupposes an established legal order, which turns norms of moral reason into

${ }^{213} / d_{.}, 738$.

${ }^{214}$ Id. See, also, Robert D. Anderson \& Frédéric Jenny, Competition Policy, Economic Development and the Possible Role of a Multi-lateral Framework on Competition Policy: Insights from the WTO Working Group on Trade and Competition Policy, in ErLINDA Medalla ed., Competition Policy In EAST Asia, Chapter 4 (2005).

${ }^{215}$ AMARTYA SEN, IDEA OF JUSTICE, 373 (2009). 
legal ones by means of legislative and compulsory judicial institutions, as well as its monopoly on the use of force. Public international law in general, and the international human rights regime in particular, it is then argued, do not possess these features. This brings us back into the age-old debate about whether international law really is law. I cannot examine here the arguments that have been made for and against this contention by countless scholars over the years. Instead, I shall simply say that if the "legality" of public international law is called into question, it is not just the pronouncements of the ESR Committee that will be called into question, but most other aspects of the corpus of public international law as well. We need, and I therefore presume the answer to be a "yes."

\section{G. Conclusion}

The central premise of this essay has been that competition law must find a way to take account of the international human right to food, either through conform-interpretation or by directly incorporating the protection of a minimum level of producer welfare consistent with the right to food into the purposes of competition laws, modifications of appreciability rules, of international law doctrines such as extraterritorial jurisdiction, and of the roles and competences of national competition regulators. Throughout this article, I have described the fundamental obligation arising from the right to food as being an obligation that all persons have physical and economic access to a minimum adequate amount of nutrition that is nutritious, free from adverse substances, and culturally acceptable. By doing so, I do not mean to deny that the impoverished and hungry may have a claim in justice to something more than just the bare minimum. It is possible that by reworking the structure of global food supply chains to allow for greater participation in decision-making processes, currently impoverished smallholders in the developing world may enjoy a living standard somewhat closer to that of the consumers they ultimately service. This essay seeks merely to be a first step in a wider conversation about how to achieve to these greater ends.

Nor should this essay, in its promotion of a corporate duty to protect, be read as a contribution to the communitarian "responsibilities" movement ${ }^{216}$ that postulates variously, that human rights must be balanced with responsibilities in order to avoid a descent into supposedly destructive forms of individualism; or that a failure to give responsibilities the same importance as human rights leads to social and moral decay supposedly characteristic of modern societies. The notion of responsibility or duty contained in this article pertains to a moral obligation to compensate those who are harmed as a consequence of one's actions.

${ }^{216}$ See, generally, the works of Amitai Etzioni, Mary Ann Glendon, David Selbourne. 
The following words by Jackson J. were spoken in the context of the provision of public education, but also capture perfectly the challenges faced today by competition law.

"Nor does our duty to apply the Bill of Rights to assertions of official authority depend upon our possession of marked competence in the field where the invasion of rights occurs. True, the task of translating the majestic generalities of the Bill of Rights, conceived as part of the pattern of liberal government in the eighteenth century, into concrete restraints on officials dealing with the problems of the twentieth century, is one to disturb self-confidence. These principles grew in soil which also produced a philosophy that the individual was the center of society, that his liberty was attainable through mere absence of governmental restraints, and that government should be entrusted with few controls, and only the mildest supervision over men's affairs. We must transplant these rights to a soil in which the laissez-faire concept or principle of noninterference has withered, at least as to economic affairs, and social advancements are increasingly sought through closer integration of society and through expanded and strengthened governmental controls. These changed conditions often deprive precedents of reliability, and cast us more than we would choose upon our own judgment. But we act in these matters not by authority of our competence, but by force of our commissions. We cannot, because of modest estimates of our competence in such specialties as public education, withhold the judgment that history authenticates as the function of this Court when liberty is infringed." ${ }^{217}$

Competition lawyers and judges will have to familiarize themselves with new concepts and institutional arrangements in order to make $20^{\text {th }}$ century provisions meet the $21^{\text {st }}$ century demands of the right to food. However, the difficulty of this task should not be exaggerated. It has been a long-standing principle of antitrust and competition law that firms with market dominance have special responsibilities towards the market. ${ }^{218}$ It is high time that we came to understand these responsibilities as including a duty to ensure that the people who create the market do not themselves go hungry.

\footnotetext{
${ }^{217}$ West Virginia State Bd. of Education v. Barnette, 319 U.S. 624, $639-640$ (1943).

${ }^{218}$ Case 322/81, Nederlandsche Banden-Industrie Michelin v. Commission [1983] ECR 3461, [1985] 1 CMLR 282, para. 57.
} 